\title{
OPEN Padina boryana mediated green synthesis of crystalline palladium nanoparticles as potential nanodrug against multidrug resistant bacteria and cancer cells
}

\author{
Hana Sonbol $^{1,4}$, Fuad Ameen ${ }^{2,4 \bowtie}$, Sami AlYahya ${ }^{3}$, Abobakr Almansob ${ }^{2}$ \& Suaad Alwakeel ${ }^{1}$
}

Green synthesized nanoparticles (NPs) have emerged as a new and promising alternative to overcome the drug resistance problem. Peculiar nano-specific features of palladium NPs (Pd-NPs) offer invaluable possibilities for clinical treatment. Due to the development of multi-drug resistance (MDR) in pathogenic bacteria and the prevalence of cancers, use of algae-mediated Pd-NPs could be a prospective substitute. Therefore, Pd-NPs were synthesized by a one-step, cost-effective, and environmentally friendly green method using the extract from a brown alga, Padina boryana (PB-extract), and evaluated for their antibacterial, antibiofilm, and anticancer activities. Pd-NPs were physicochemically characterized for size, shape, morphology, surface area, charge, atomic composition, crystal structure, and capping of Pd-NPs by PB-extract biomolecules by various techniques. The data revealed crystalline Pd-NPs with an average diameter of $8.7 \mathrm{~nm}$, crystal size/structure of $11.16 \mathrm{~nm} /$ face-centered cubic, lattice $d$-spacing of $0.226 \mathrm{~nm}, 28.31 \%$ as atomic percentage, surface area of $16.1 \mathrm{~m}^{2} / \mathrm{g}$, hydrodynamic size of $48 \mathrm{~nm}$, and zeta-potential of $-28.7 \pm 1.6 \mathrm{mV}$. Fourier-transform infrared spectroscopy (FT-IR) analysis revealed the role of PB-extract in capping of Pd-NPs by various functional groups such as $-\mathrm{OH}, \mathrm{C}=\mathrm{C}, \mathrm{C}-\mathrm{O}$, and $\mathrm{C}-\mathrm{N}$ from phenols, aliphatic hydrocarbons, aromatic rings, and aliphatic amine. Out of 31, 23 compounds were found involved in biosynthesis by Gas chromatography-mass spectrometry (GC-MS) analysis. Isolated strains were identified as MDR Staphylococcus aureus, Escherichia fergusonii, Acinetobacter pittii, Pseudomonas aeruginosa, Aeromonas enteropelogenes, and Proteus mirabilis and Pd-NPs exhibited strong antibacterial/antibiofilm activities against them with minimum inhibitory concentration (MIC) in the range of $62.5-125 \mu \mathrm{g} / \mathrm{mL}$. Moreover, cell viability assays showed concentration-dependent anti-proliferation of breast cancer MCF-7 cells. Pd-NPs also enhanced mRNA expression of apoptotic marker genes in the order: $p 53$ ( 5.5 -folds) $>$ bax ( 3.5 -folds) $>$ caspase- 3 ( 3 -folds) $>$ caspase- 9 ( 2 -folds) at $125 \mu \mathrm{g} / \mathrm{mL}$. This study suggested the possible role of PB-extract capped Pd-NPs for successful clinical management of MDR pathogens and breast cancer cells.

Nanotechnology manipulating the matter at molecular scale has tremendously revolutionized the field of science ${ }^{1}$. Nanoparticles (NPs) with dimeter between $1-100 \mathrm{~nm}$ possess distinguished physicochemical properties over bulk-materials including higher surface area to volume (S/V) ratio, surface energy, and chemical reactivity ${ }^{2}$. Physical or chemical methods of NPs synthesis use harmful toxic substances and high temperatures/pressure which make them environmentally unfriendly and expensive ${ }^{3}$. Moreover, NPs synthesized using toxic chemicals when used medically can also damage human health. Therefore, water extracts prepared from various organisms such as plants (fruit, leaves, roots, and bark) ${ }^{4}$, algae (cyanobacteria and higher algae) $)^{5}$, bacteria (cell supernatant) ${ }^{6}$, and fungi (extra mycelial/cellular biomolecules $)^{7}$ have been utilized to fabricate different metal-based NPs. Among these, algae mediated synthesis of NPs is relatively less explored. This approach is not only economical

${ }^{1}$ Department of Biology, College of Science, Princess Nourah Bint Abdulrahman University, Riyadh, Saudi Arabia. ${ }^{2}$ Department of Botany \& Microbiology, College of Science, King Saud University, Riyadh 11451, Saudi Arabia. ${ }^{3}$ National Center for Biotechnology, King Abdulaziz City for Science \& Technology, Riyadh, Saudi Arabia. ${ }^{4}$ These authors contributed equally: Hana Sonbol and Fuad Ameen. ${ }^{\square}$ email: fuadameen@ksu.edu.sa 
but also poses negligible risk to environmental health ${ }^{8}$. Besides, algae can be found easily in bulk quantities at coastal sites such as coastal regions of Saudi Arabia ${ }^{9,10}$. Therefore, metal based NPs synthesis using algal extracts have attracted greater attention for various applications. For example, Ag-NPs from Botryococcus braunii ${ }^{11}$, AuNPs from Egregia $s p^{12}$, CuO-NPs from Bifurcaria bifurcata ${ }^{13}$, and $\mathrm{Fe}_{3} \mathrm{O}_{4}$-NPs from Sargassum acinarium ${ }^{14}$ have been synthesized. In particular, brown algal (seaweed) species have scarcely been reported mechanistically to produce NPs of platinum group. Few studies done in recent past have documented the synthesis of Pt-NPs from brown seaweed Padina gymnospora ${ }^{15}$ and Pd-NPs from blue-green algae Spirulina platensis ${ }^{16}$. So far no study has reported the mechanism of synthesis of Pd-NPs from brown alga Padina boryana and their antibacterial, antibiofilm, and anticancer potential.

Multidrug resistance (MDR) in clinical pathogenic bacteria and cancerous cells is of huge concern due to growing worldwide incidences of MDR and low efficacy of available drugs ${ }^{17,18}$. Among the clinical bacterial pathogens, S. aureus, P. aeruginosa, E. fergusonii, A. pittii, A. enteropelogenes, and P. mirabilis have affected the human population due to the development of antibiotic resistance mechanisms in bacteria ${ }^{19}$. Also, breast cancer is a recognized cause of death worldwide and has been the fourth in the list of cancer triggered mortalities in the USA alone ${ }^{20}$. Therefore, new nano-based strategies such as algal-derived metabolites capped NPs could be adopted after successful clinical trials.

The Pd-NPs have found applications in catalysis for wastewater remediation ${ }^{21}$, degradation of pollutant dyes ${ }^{22}$, bactericidal and antifungal activities, and anticancer activities ${ }^{23}$. Indeed, there are other metal and metal oxide NPs being used in various biomedical applications including antibacterial and anticancer. These NPs are Au, $\mathrm{Ag}, \mathrm{Fe}, \mathrm{ZnO}$, and $\mathrm{CuO}$ etc. However, the noble Pd-NPs have shown excellent physicochemical features like high photocatalytic activity, remarkable chemical stability, good thermal stability, optical and electronic properties ${ }^{24}$. Especially in pharmaceutical industry, Pd-NPs catalyse many different reactions including catalysis resulting in $\mathrm{C}-\mathrm{C}$ bond formation and oxidation processes ${ }^{25,26}$. As compared to other nanoscale materials such as $\mathrm{Au}$ and $\mathrm{Ag}$ nanospheres, plasmonic Pd nanospheres have shown higher susceptibility to refractive index changes ${ }^{27}$. Besides, Pd-NPs exert prominent inhibition of several cancer cell lines and bacterial strains. Besides with multifarious applications, Pd-NPs are able to enhance the biomedical diagnosis and clinical therapies with minimum side effects. However, due to thermodynamic instability, Pd-NPs usually form aggregates which limit their broader biological applications. To this end, algal extract mediated fabrication might stabilize the Pd-NPs by efficient surface adsorption of algal biomolecules. Bioactive molecules present in algal extracts such as polysaccharides, proteins, fatty acids, phenolics, flavonoids, etc. ${ }^{28}$ can efficiently reduce $\mathrm{Pd}^{2+}$ ions and functionalize/cap growing seeds of NPs thus reducing the size of final Pd-NPs. Extracts of $P$. boryana are also rich in biologically active compounds including compounds with high phenolic content ${ }^{29}$ including flavonoids and tannins, proteins and steroids ${ }^{30}$ with antimicrobial activities. P. boryana extract also inhibits cellular tyrosinase levels and melanin synthesis which suggests its cosmeceutical and medicinal applications ${ }^{31}$.

Considering the clinical importance of $P$. boryana extract and Pd-NPs, this study for the first time was designed comprehensively to achieve the following objectives: (i) synthesis and capping of Pd-NPs by biomolecules of $P$. boryana extract and its characterization by UV-visible, X-ray diffraction (XRD), and energy dispersive X-ray (EDX) spectroscopy, scanning and transmission electron microscopy (SEM/TEM), dynamic light scattering (DLS), and zeta-potential, (ii) determination of P. boryana biomolecules adsorption on the surface of Pd-NPs and their role in capping by FT-IR spectroscopic and GC-MS analyses, (iii) isolation and identification of multi drug-resistant clinical bacteria, (iv) assessment of bacterial growth and biofilm inhibiting potential of PB-capped Pd-NPs, and (v) MCF-7 cell anti-proliferative and apoptosis inducing potential of PB-capped Pd-NPs.

\section{Materials and methods}

Collection and preparation of aqueous extract of $\boldsymbol{P}$. boryana. Brown seaweed of P. boryana was collected from the Saudi coastal region of the Arabian Gulf (latitude $26^{\circ} 11^{\prime} 45.8^{\prime \prime} \mathrm{N}$ and longitude $50^{\circ} 01^{\prime} 37.8^{\prime \prime}$ E). Samples were transported to the laboratory in sterile polystyrene containers. Collected samples were washed well several times with running tap water followed by sterile deionized water (DIW) to remove unwanted debris. Samples were shade dried for 40 days in an incubator at $28^{\circ} \mathrm{C}$. Dried samples were powdered using a mortar and pestle and sieved through a mesh to obtain a fine powder. To prepare the extract, dried $P$. boryana powder ( $5 \mathrm{~g})$ was added to sterile $100 \mathrm{~mL}$ DIW followed by ultrasonication at low amplitude (20\%) for $40 \mathrm{~min}$. The mixture was then incubated on a magnetic stirrer at $120 \mathrm{r} / \mathrm{min}$ for $24 \mathrm{~h}$. The extract was filtered first through a sterile blotting paper and then sterile Whatman No. 1 filter discs using a vacuum filtration assembly. Aqueous extract of $P$. boryana (PB extract) was stored in $50 \mathrm{~mL}$ aliquots at $-20^{\circ} \mathrm{C}$ until further use.

Green fabrication of PB-capped Pd-NPs. Pd-NPs were prepared by facile one-pot fabrication method using green PB-extract. A $5 \mathrm{~mL}$ of PB-extract was mixed with $100 \mathrm{~mL}$ of $10 \mathrm{mM}$ disodium tetrachloropalladate (II) $\left(\mathrm{Na}_{2} \mathrm{PdCl}_{4}\right)$ prepared in sterile DIW procured from Sigma Aldrich, USA (product code-379808 with $99.99 \%$ purity). The mixture was vigorously stirred using a magnetic stirrer at $200 \mathrm{r} / \mathrm{min}$ for $2 \mathrm{~h}$ maintaining the stirring temperature at $60{ }^{\circ} \mathrm{C}$. Sterile experimental conditions were made throughout the synthesis and, to avoid the photo mediated changes in PB-extract, dark condition was maintained during Pd-NPs synthesis by wrapping the glass beakers by $0.024 \mathrm{~mm}$ thick aluminum foil. The color of PB-extract was pale yellow which became dark brown denoting the successful synthesis of Pd-NPs. After completion of the reaction, the dark solution of PdNPs was centrifuged at 10,000 r/min for $30 \mathrm{~min}$ and the pellet was separated from the supernatant. Pellets were collected and supernatants were again centrifuged at 12,000 r/min for $30 \mathrm{~min}$ to collect remaining smaller sized Pd-NPs. The pellets were washed at least thrice with sterile DIW followed by freeze-drying. Freeze-dried powder of PB-capped Pd-NPs was stored in cleaned brown bottles till characterization and assessment of biocidal activities. 
Physicochemical characterization of PB extract-capped Pd-NPs. UV-Vis, EDX, and SEM analyses. Liquid samples of $\mathrm{PB}$-extract, $\mathrm{Na}_{2} \mathrm{PdCl}_{4}$, and $\mathrm{PB}$ extract-capped Pd-NPs were checked for their absorption in the UV-visible range $(280-600 \mathrm{~nm})$ using double beam operation of PerkinElmer Lambda 35 spectrophotometer (Waltman, MA, USA). To measure the surface morphology, the powder of Pd-NPs was put on to a carbon tape and aluminum stub carrying carbon tape was analyzed by a scanning electron microscope attached with EDX at an accelerating voltage of $15 \mathrm{kV}$ (SEM-EDS; JEOL-64000, Tokyo, Japan).

Structure, shape, and size determination of PB extract-capped Pd-NPs. Transmission electron microscope (JEM1011, JEOL, Tokyo, Japan) was used for the determination of average diameter and shape of Pd-NPs at $200 \mathrm{kV}$ energy. The aqueous suspension $(15 \mu \mathrm{L})$ of Pd-NPs was put on a $\mathrm{Cu}$-grid followed by drying at $80{ }^{\circ} \mathrm{C}$ for $5 \mathrm{~h}$. Prepared grids were analyzed by TEM. To check the crystallinity and phase purity, XRD analysis was performed on Bruker D8 Discover instrument. $\mathrm{Cu}$-Ka radiation $(\lambda=1.54 \AA)$ was used to obtain the diffraction pattern and data was recorded at $20-80^{\circ}$ two-theta $(2 \theta)$ angle.

Hydrodynamic size, zeta-potential, and surface area measurement. To obtain the hydrodynamic size, $50 \mu \mathrm{g} / \mathrm{mL}$ suspension of Pd-NPs was prepared in DIW and ultrasonicated at $40 \%$ amplitude for $15 \mathrm{~min}$. The Pd-NPs suspension was then subjected to analysis by a Zeta Sizer Nano-ZS90, Malvern, UK. The zeta-potential of Pd-NPs was recorded as an average of 20 readings. Specific surface area measurement of PB-capped Pd-NPs was done following Brunauer-Emmett-Teller (BET) analysis using Autosorb-iQ-MP/XR surface area analyzer (Quantachrome Instruments, USA).

Determination of surface functional groups and compounds of PB-extract and Pd-NPs. To detect the adsorption of functional groups, FT-IR analysis of PB-extract and Pd-NPs was recorded in attenuated total reflectance (ATR) mode on the PerkinElmer system 2000 instrument. The spectra for each sample were scanned three times and average values of percent transmittance were plotted against wavelength $\left(4000-400 \mathrm{~cm}^{-1}\right)$. GC-MS analysis of hexane extracts of $P$. boryana and PB-extract capped Pd-NPs was performed on Shimadzu QP-2010 Plus with Thermal Desorption System TD-20 instrument. Conditions for analysis were kept as follows: He flow at $1.2 \mathrm{~mL} / \mathrm{min}$, oven temperature from 80 to $260{ }^{\circ} \mathrm{C}$ at $4{ }^{\circ} \mathrm{C} / \mathrm{min}$, for $5 \mathrm{~min}$, interface/inlet temperature were set as $280 / 250^{\circ} \mathrm{C}$. A $0.2 \mathrm{~mL}$ solution was injected at a $10: 1$ split ration at $70 \mathrm{eV}$. Data for signals obtained for various molecules such as retention time, peak percentage area, molecular mass, etc. was recorded based on the interpretation of the National Institute of Standards and Technology (NIST) library.

Isolation and characterization of clinical bacterial pathogens. Samples for isolation of clinical bacteria were collected from fluid and sputum of immunocompromised patients diagnosed with respiratory infections following our earlier described method $^{32}$. After biochemical and morphological identification, antibiotic-resistant isolated cultures were molecularly characterized by partially sequencing $16 \mathrm{~S}$ rRNA gene using universal primers 785F (5' -GGATTAGATACCCTGGTA-3') and 907R (5'-CCGTCAATTCMTTTRAGTTT-3') following our previously demonstrated methods of $16 \mathrm{~S}$ rDNA amplification and Sanger's dideoxy sequencing. The sequences were processed using BioEdit software 7.2.4. For similarity search, the BLASTn search tool of NCBI was used. The processed sequences for isolated bacterial strains were submitted to the GenBank database and accession numbers were obtained. The strains were stored in Luria Bertani (LB) broth supplemented with glycerol (40\%) at $-70{ }^{\circ} \mathrm{C}$ in duplicates until further use. Detailed method of phylogenetic analysis can be found in supplementary information.

Antimicrobial drug resistance profiling of bacterial isolates by disc susceptibility test. Drug resistance was checked by Kirby-Bauer's disc diffusion assay of antibiotics with known disc potency on LB agar media following the guidelines of the Clinical and Laboratory Standards Institute (CLSI, 2016) ${ }^{33}$. The size of the inhibition zone around antibiotic discs was measured and captioned as sensitive (S), intermediate (I), and resistant $(\mathrm{R})$ based on the manufacturer's criteria. Control strains of E. coli ATCC-25922 and P. aeruginosa ATCC27853 were used.

Evaluation of the antibacterial potential of PB-capped Pd-NPs. Antibacterial well-diffusion assay. The PB-capped Pd-NPs were screened for their antibacterial potential by agar well diffusion method against $S$. aureus strain FA-1, E. fergusonii strain FA-5, A. pittii strain FA-6, P. aeruginosa strain FA-7, A. enteropelogenes strain FA-8, and P. mirabilis strain FA-9. A $100 \mu \mathrm{L}$ culture $\left(\sim 1 \times 10^{8}\right.$ cells $\left./ \mathrm{mL}\right)$ of each bacterium was separately spread plated on LB agar plates. Wells of $8 \mathrm{~mm}$ size were cut and the base was sealed with $0.6 \%$ agar. A $100 \mu \mathrm{L}$ from Pd-NPs stock solution $(1 \mathrm{mg} / \mathrm{mL})$ was added to wells. Negative $(100 \mu \mathrm{L} \mathrm{PB}$-extract) and positive (gentamicin $10 \mu \mathrm{g} / \mathrm{disc}$ ) controls were also incorporated. Petri plates were incubated for $24 \mathrm{~h}$ at $37^{\circ} \mathrm{C}$ and results of inhibition zones were compared.

Determination of MIC by colony forming unit (CFU) count method. A $20 \mathrm{~mL}$ of LB broth in $50 \mathrm{~mL}$ capacity conical flasks amended with 7.81-250 $\mu \mathrm{g}$ PB-extract capped Pd-NPs/mL) was inoculated with young bacterial cultures in triplicates. Flasks were incubated in a shaker incubator at $120 \mathrm{r} / \mathrm{min}$ constant stirring, $37^{\circ} \mathrm{C}$ for $24 \mathrm{~h}$. After $24 \mathrm{~h}$ incubation, $100 \mu \mathrm{L}$ culture from each test concentration for each test bacterium was spread plated on LB agar and after incubation under static conditions, the number of colonies was counted and converted to $\mathrm{CFU} / \mathrm{mL}$. The concentration at which the number of cells was negligible, was taken as MIC. 
Bacterial growth measurement as a function of PB-capped Pd-NPs concentration. To observe the concentrationdependent growth inhibition of bacterial cultures, the cultures were grown with 7.81-250 $\mu \mathrm{gPd}-\mathrm{NPs} / \mathrm{mL}$ in LB broth as mentioned for MIC determination. $\log _{10} \mathrm{CFU} / \mathrm{mL}$ were graphically plotted with increasing concentration of PB-capped Pd-NPs.

Impact of PB-capped Pd-NPs on the bacterial cell membrane. A fluorescence-based method was used to detect membrane compromised cells. Bacterial cells were grown in LB broth for $12 \mathrm{~h}$. Cultures were centrifuged, cell pellets were washed with 1X sterile phosphate buffered saline (PBS), and re-suspended in $5 \mathrm{ml}$ PBS followed by treatment with Pd-NPs at 7.81-250 $\mu \mathrm{g} / \mathrm{mL}$ at continuous stirring $(120 \mathrm{r} / \mathrm{min})$ for $2 \mathrm{~h}$. Thereafter, a fluorescent DNA tag called propidium iodide (PI) was added maintaining the final concentration of PI as $25 \mu \mathrm{M}$. After $20 \mathrm{~min}$ of incubation at room temperature, cells were again washed thrice with sterile 1X PBS to remove the unbound PI, and slides were prepared for confocal laser scanning microscopy (CLSM) and visualized under Leica TCS SPE microscope. The number of cells with membrane defects emitting red fluorescence of PI were enumerated from the three best preparations and mean values were plotted as a function of Pd-NPs concentration.

Impact of PB-capped Pd-NPs on biofilm-forming ability of bacterial isolates. Biofilm-formation was determined by crystal violet (CV) microtiter plate method. Bacterial isolates were first checked for biofilm formation and compared with biofilms of standard biofilm-forming strains of E. coli ATCC-25922, S. aureus ATCC-9144, and P. aeruginosa ATCC-27853 by broth dilution method and optical microscopy. To determine the absorbance based biofilm formation, $0.1 \mathrm{~mL}$ young culture $\left(\sim 1 \times 10^{7} \mathrm{CFU} / \mathrm{mL}\right)$ grown in LB broth from each isolate was added to respective microtiter wells in triplicates. The cultures were added with appropriate stock concentration of PB-extract capped Pd-NPs maintaining the final concentration as 3.9-250 $\mu \mathrm{g} / \mathrm{mL}$. Two negative controls: (i) broth only, (ii) broth $+3.9-250 \mu \mathrm{g} / \mathrm{mL}$ Pd-NPs, and one positive control (bacterial culture only) were run in parallel. A $2 \%$ sucrose was also added to induce the production of exopolysaccharides for biofilm formation. After incubation for $48 \mathrm{~h}$ at $37{ }^{\circ} \mathrm{C}$, the wells were rinsed gently sterile PBS and then added with $1 \%$ CV solution $(200 \mu \mathrm{L})$ followed by incubation for $20 \mathrm{~min}$. Wells were again rinsed thrice with PBS, dried under laminar airflow, and the CV remained in biofilm was solubilized by the addition of $95 \%$ ethanol. The absorbance at $600 \mathrm{~nm}$ was measured. Bare surface Pd-NPs (bare-PdNPs) procured from Sigma-Aldrich, USA (product code-686,468) with an average particle diameter of $<25 \mathrm{~nm}$ (determined by TEM) were also tested at 15.62 , $31.25,62.5 \mu \mathrm{g} / \mathrm{mL}$ and the results were compared with PB-extract capped Pd-NPs. The data was interpreted as percent biofilm formation over positive control.

Cellular anti-cancer activity and apoptosis induced by PB-capped Pd-NPs in MCF-7 cells. The anti-cancer potential of PB-capped Pd-NPs was determined in vitro by 3-(4,5-dimethylthiazol-2-yl)-2,5-diphenyl tetrazolium bromide (MTT) and neutral red uptake (NRU) assays. MCF-7 cells were grown following the detailed method described in the supplementary information. The cell culture media (Dulbecco's Modified Eagle's Medium; DMEM) was supplemented with 7.81-250 $\mu \mathrm{g} / \mathrm{mL}$ PB-extract capped Pd-NPs and sonicated $(15 \mathrm{~min}$ at $40 \mathrm{~W})$. MCF-7 cells $\left(1 \times 10^{4} / \mathrm{mL}\right)$ were then treated with NPs for $24 \mathrm{~h}$ in DMEM medium in microtiter wells of 96-well polystyrene plate. Experiment with bare surface Pd-NPs at 15.62, 31.25, $62.5 \mu \mathrm{g} / \mathrm{mL}$ was also run in parallel and the results were compared with PB-extract capped Pd-NPs. After incubation, DMEM was gently discarded and cells were rinsed with PBS (1X). MTT at $5 \mathrm{mg} / \mathrm{mL}$ rate was added to each well and incubated further for $4 \mathrm{~h}$ at $37^{\circ} \mathrm{C}$. MTT retained by cells was solubilized by $0.2 \mathrm{~mL}$ dimethyl sulfoxide (DMSO) absorbance at $\lambda_{\max }=550 \mathrm{~nm}$ was recorded. Similarly, the NRU assay was performed. After the treatment of MCF-7 cells with Pd-NPs for $24 \mathrm{~h}$, DMEM was supplied afresh carrying $50 \mu \mathrm{g} / \mathrm{mL}$ of neutral red. Further incubation of three hours was given. Microtiter wells containing this mixture were rinsed with a combination of $\mathrm{HCHO}$ and $\mathrm{CaCl}_{2}$ (mixed at a ratio of $0.5: 1 \%$ ). Thereafter, a mix of $\mathrm{C}_{2} \mathrm{H}_{5} \mathrm{OH}(50 \%)$ and $\mathrm{CH}_{3} \mathrm{COOH}(1 \%)$ was added to wells and incubated at $37^{\circ} \mathrm{C}$ for $20 \mathrm{~min}$. Absorbance at $\lambda_{\max }=540 \mathrm{~nm}$ was recorded. Percent cell viability was plotted over untreated control with an increasing dose rate of PB-extract capped Pd-NPs.

To assess the apoptosis induced by Pd-NPs, MCF-7 cells were treated with 62.5 and $125 \mu \mathrm{g} / \mathrm{mL}$ concentration of Pd-NPs. Total RNA was extracted from cells and purified by a commercially available RNA purification kit procured from Roche, Mannheim, Germany as per manufacturer's instructions. Extracted RNA was visualized following agarose gel electrophoresis (1\%) and quantification of RNA was done by a NanoDrop spectrophotometer. The cDNA from RNAs was synthesized by using the Fermentas cDNA synthesis kit (Burlington, ON, Canada). cDNA synthesis was performed as per the protocol provided by the manufacturer. Primer sequences for housekeeping GAPDH gene (for normalization of gene expression) and four apoptotic genes namely bax, p53, caspase-9, and caspase-3 are provided in the supplementary information (Table S1). PCR amplification of genes was performed in 35 cycles following the program: first cycle $95^{\circ} \mathrm{C}$ for ten minutes; 35 cycles at $95^{\circ} \mathrm{C}$ for $15 \mathrm{~s}, 60^{\circ} \mathrm{C}$ for $30 \mathrm{~s}$, and $72^{\circ} \mathrm{C}$ for $30 \mathrm{~s}$. DIW was used as a template for negative control. Gene expression data were analyzed by ${ }^{2-\Delta \Delta} \mathrm{Ct}$ method fold changes in gene expression were compared with control.

Data analysis. Each experiment was performed three times with triplicate samples for each test concentration. Data shows mean values and error bars represent standard deviation (S.D.). Significant differences between the values were calculated by student's t-test at $95 \%$ confidence limit using Sigma Plot 14.0. All methods were carried out in accordance with relevant guidelines and regulations. Clinical cultures of bacteria were isolated from pus/wound samples of the registered patients and informed consent was obtained. Experimental protocols were approved by institutional committee of the University as and when required. No consent from ethical committee was required for sample collection for the isolation of bacteria. 
Ethics statement. All methods were carried out in accordance with relevant guidelines and regulations. Experimental protocols were approved by institutional committee of the Princess Nourah Bint Abdulrahman University, Registration No. H-01-R-059.

\section{Results and discussion}

Many physiological or structural changes occur alone or simultaneously in bacteria when it is encountered by an antibiotic. The following are major antibiotic resistance mechanisms reported in clinical bacteria: (i) occurrence of bacterial mutations, (ii) horizontal gene transfer, (iii) destruction/modification of antibiotic molecules, (iv) decrease in cell membrane permeability to inhibit antibiotic penetration, (v) higher expression of efflux pumps in the membrane, and (vi) alteration of antibiotic target sites ${ }^{34}$. Moreover, bacterial species can form biofilms that is highly resistant towards antibiotics than planktonic cells, sometimes $>1000 \mathrm{folds}^{35}$. On the other hand, the development of cancers and inefficient cure by available anti-cancer drugs further complicates their clinical treatments. Based on the drug sensitivity/resistance profile, cancers could be also be categorized as MDR cancer ${ }^{36}$. Therefore, environmentally sustainable, non-toxic, and cost-effective nano-therapeutics are in trend to treat such resistance in clinical bacteria and cancer cells.

So far, few studies report the utilization of brown seaweed (marine algae) for Pd-NPs production ${ }^{16,22}$ even though the marine algal population is chemically rich possesses a wide range of compounds with promising anti-oxidant, anti-cancer, anti-inflammatory, and anti-microbial activities. The rich biomolecular composition of PB-extract and previous evidences on Pd-NPs biological activity prompted us to investigate the role of PBextract in capping of Pd-NPs and interactions with six clinical bacteria and human breast cancer (MCF-7) cell line. The capping of NPs (i.e. adsorption of molecules on the surface of NPs) decides its final morphology and thus prevents the overgrowth of NPs. The method for synthesis and capping of Pd-NPs by PB-extract is detailed in Fig. 1 depicting (i) bio-reduction of $\mathrm{Pd}^{2+}$ ions to $\mathrm{Pd}^{0}$ seeds and (ii) capping/stabilization of Pd-NPs growth by molecules of PB-extract via surface adsorption. Production of Pd-NPs started following the reduction of $\mathrm{Pd}^{2+}$ to $\mathrm{Pd}^{0}$ from electrons liberated mainly from the reducing sugars and polyphenols containing biomolecules of $P$. boryana extract. As a result, the color of solution changed drastically from pale yellow to dark brown. This could be well corroborated with earlier observations ${ }^{37}$, where leaf biomolecules of Solanum trilobatum while interacting with $\mathrm{Pd}^{2+}$ ions gave dark precipitation from the reaction mixture which could be due to surface plasmon resonance (SPR) owing to the collective oscillation of electrons. The biomolecules of PB-extract when donating electrons for $\mathrm{Pd}^{2+}$ ions reduction are oxidized and are expected to form intermediate Pd-organic complexes. Ions are then converted to $\mathrm{Pd}^{0}$ by free electrons generated in the medium ${ }^{38}$. Frequent collisions among $\mathrm{Pd}^{0}$ atoms lead to the production and growth of Pd-NPs that are meanwhile capped by other organics of PB-extract giving specific size and shape to growing Pd-NPs seeds.

UV-vis spectroscopic analysis. NPs have optical features which give a preliminary idea about their shape, size, and $\mathrm{SPR}^{39}$. The comparative UV-vis spectra (Fig. 2) showed a broad absorption of PB-extract with a peak overlapping the UV and visible region. The precursor salt $\left(\mathrm{Na}_{2} \mathrm{PdCl}_{4}\right)$ showed two characteristics peaks at $311 \mathrm{~nm}$ and $402 \mathrm{~nm}$, while Pd-NPs exhibited a sharp peak at $293 \mathrm{~nm}$. The absorption near to $293 \mathrm{~nm}$ by PdNPs has also been observed in other studies such as $268 \mathrm{~nm}^{22}$. In $\mathrm{Na}_{2} \mathrm{PdCl}_{4}$, two signals can be assigned to the transition of ligand to metal charge transfer between $\mathrm{Pd}^{2+}$ and $\mathrm{Cl}^{-}$. Absence of these two signals in the Pd-NPs spectrum advocates reduction of $\mathrm{Pd}^{2+}$ ions to $\mathrm{NPs}^{40}$ as also visually observed (Fig. 2 inset).

Surface morphology and elemental composition of PB-capped Pd-NPs. The morphological analysis of dehydrated powder of PB-capped Pd-NPs through SEM is shown in Fig. 3A,B at two different magnifications. Aggregates of variable sizes were recorded, however, the shape was pleomorphic. The elemental composition of Pd-NPs revealed the presence of Pd with carbon, oxygen, and chlorine (Fig. 3C). The Pd-NPs after synthesis were washed many times to remove the ions and unbound $\mathrm{PB}$-extract, therefore, $\mathrm{C}, \mathrm{O}$, and $\mathrm{Cl}$ could appear in EDX spectra from the algal extract. The percentage of Pd was high in the EDX spectrum as $28.31 \%$ (Fig. 3C inset) and the peak clarity of EDX confirmed the purity of synthesized Pd-NPs. The peak at $3.1 \mathrm{keV}$ in the EDX spectrum represents Pd as reported earlier ${ }^{41}$.

Average Diameter, crystalline size, and structure of NPs. The TEM micrographs showed spherical shape Pd-NPs (Fig. 4A,B) with a narrow range of particle size distribution from 5 to $20 \mathrm{~nm}$ (Fig. 4C). The average particle diameter calculated from the TEM size distribution was $8.7 \mathrm{~nm}$. Pd-NPs were found well dispersed and agglomeration was absent. There was least direct particle-to-particle adherence and nil fusion of Pd-NPs during TEM analysis that could be due to the corona formation by biomolecules of PB-extract during capping. In Fig. 4B, the lattice $d$-spacing of $0.226 \mathrm{~nm}$ is shown while the distance between planes was measured. This $d$-spacing confirmed the crystallinity of PB-capped Pd-NPs. The XRD pattern of Pd-NPs (Fig. 4D) revealed one major (111) and three minor signals (200), (220), and (311) which were sharp and intense. The crystalline plane of (111) was well-matched with Pd ( $d$-spacing of $0.23 \mathrm{~nm})$ and revealed an FCC structure. The XRD derived average particle size was calculated as $11.16 \mathrm{~nm}$ by using Debye-Scherrer's equation which is good agreement with TEM size. Peaks could corroborate with the standard JCPDS file of crystalline Pd (file no. 05-0681) ${ }^{42}$. Thus XRD and TEM data confirmed the purity and crystalline nature which is consistent with other plant and green algae mediated fabrication studies of Pd-NPs ${ }^{16,43}$, however, the antibiofilm and anti-cancer activities were lacking.

Surface area, hydrodynamic size, and zeta-potential. The surface area recorded for Pd-NPs was $16.1 \mathrm{~m}^{2} / \mathrm{g}$. DLS analysis revealed the average hydrodynamic size of Pd-NPs as $48 \pm 3.8 \mathrm{~nm}$ while zeta-potential 


\section{Padina boryana Mediated Green Synthesis of Crystalline Palladium Nanoparticles as Potential Nano-drug against MDR Bacteria and Cancer Cells}
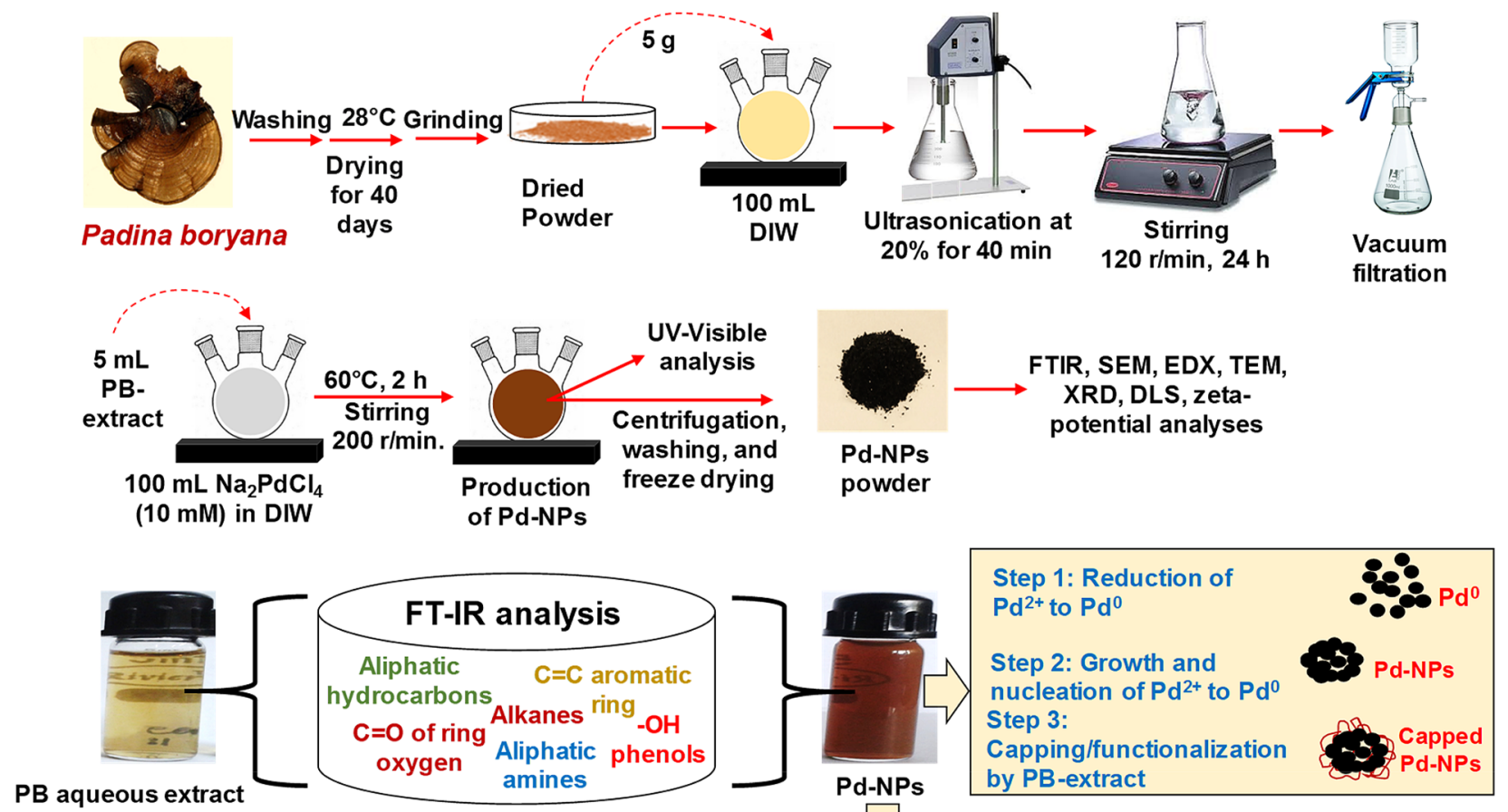

PB aqueous extract
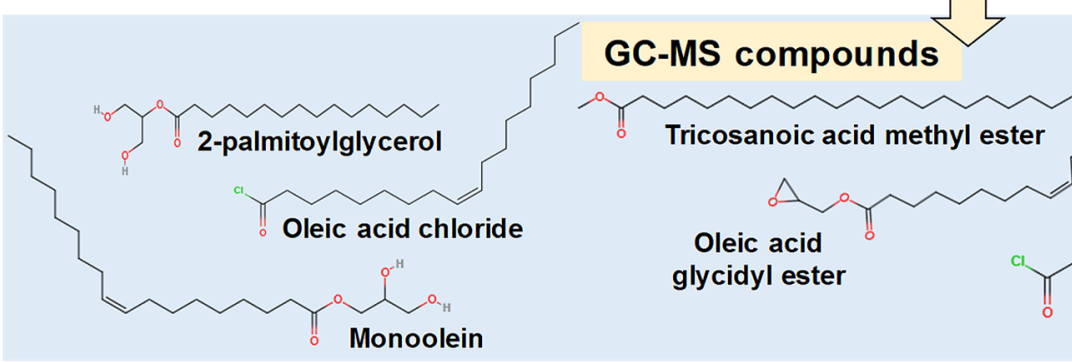
Oleic acid
glycidyl ester

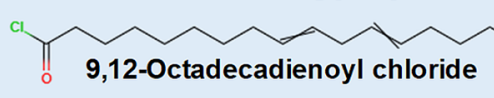

Figure 1. Scheme for P. boryana extract preparation, Pd-NPs fabrication, their characterization, and determination of capping by various techniques.

was found as $-28.7 \pm 1.6 \mathrm{mV}$ (Fig. 5A,B). The increase in size compared to the primary size measured by TEM and XRD shows some sort of particle aggregation in the aqueous solution which depends on the frequency of NPs collisions as inter-particular interactions increases. Due to these collisions, the average path length covered by NPs decreases thereby increasing the hydrodynamic size ${ }^{44}$. A similar kind of variation has been seen in another study where size of Pd-NPs measured by DLS increased up to $24.20 \mathrm{~nm}$ as compared to size (4 nm) measured by TEM ${ }^{38}$ which was suggested due to the presence of biomolecules from Delonix regia. The stability of Pd-NPs was assessed by determining the zeta-potential that gives information about surface electrostatic potential and movement of NPs in the suspension. The zeta-potential of $-28.7 \pm 1.6 \mathrm{mV}$ denotes sufficient stability of Pd-NPs for effective biological applications. This could probably be due to the efficient capping of Pd-NPs by biomolecules of algal extract producing repulsion among Pd-NPs in solution ${ }^{45}$.

Surface functional groups/biomolecules analyzed by FT-IR and GC-MS. The IR signals detected for extract and NPs (Fig. 5C) are assigned to various functional groups in Table 1. All the major signals detected for extract were also found in Pd-NPs except one which was for C-H stretch at $2086 \mathrm{~cm}^{-1}$. The FT-IR spectrum of Pd-NPs suggests the possible role of $-\mathrm{OH}$ functional groups having compounds such as polyols including terpenoids, tannins, saponins, etc. ${ }^{46}$ forming complex with Pd-NPs as revealed by narrowing of the peak. The shift in transmittance of FT-IR signals of Pd-NPs as compared to extract could be due to possible interactions of functional groups with metal ions (during reduction) and atoms or smaller NPs (during capping) as observed in the current study ${ }^{47}$. The signals at 2986,1643 , and $1062 \mathrm{~cm}^{-1}$ of extract were shifted to 2974,1637 , and $1059 \mathrm{~cm}^{-1}$ in Pd-NPs after bio-reduction suggesting the involvement of aliphatic hydrocarbons, aromatic rings, aliphatic amines ${ }^{48,49}$. 


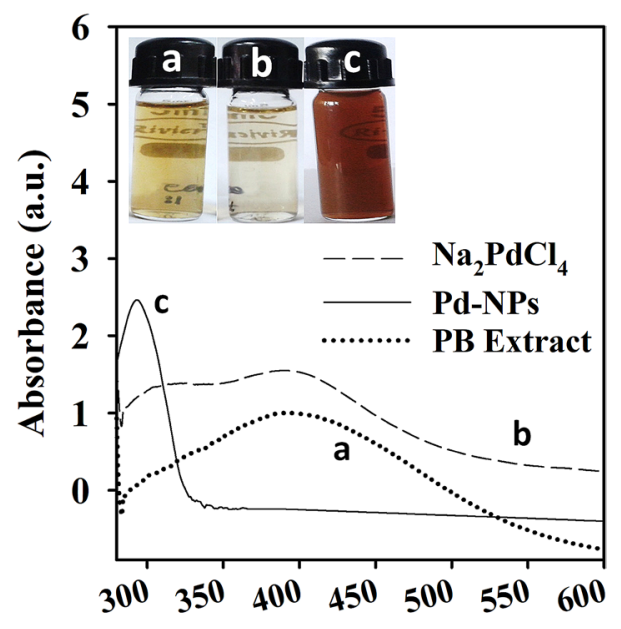

Wavelength (nm)

Figure 2. UV-Visible spectroscopic analysis of $P$. boryana aqueous extract (A), $\mathrm{Na}_{2} \mathrm{PdCl}_{4}(\mathbf{B})$, and Pd-NPs. Glass vials in inset represent the color change of $\mathrm{PB}$-extract and $\mathrm{Na}_{2} \mathrm{PdCl}_{4}$ mixture after Pd-NPs synthesis.
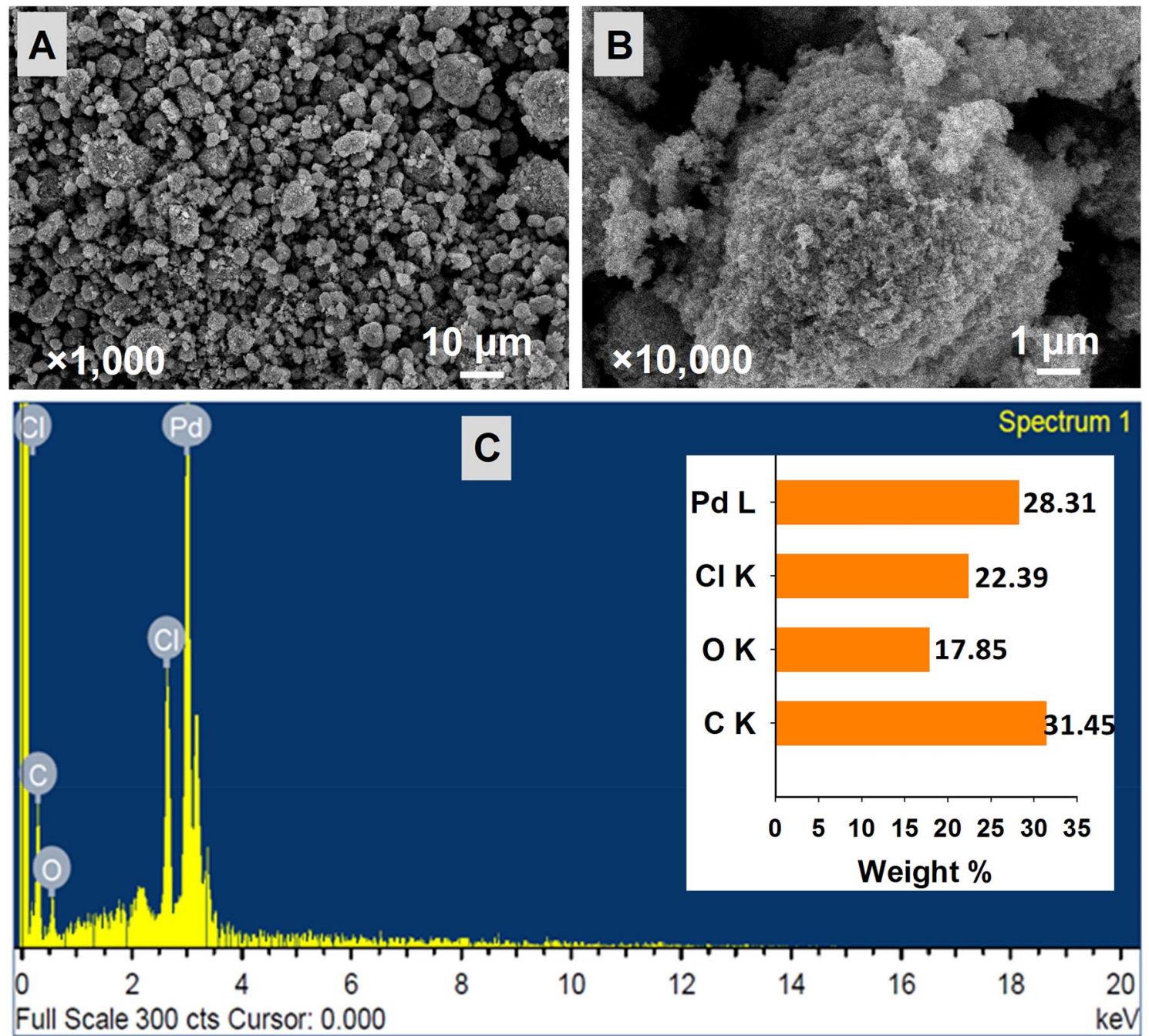

Figure 3. Determination of surface morphology of PB extract-capped Pd-NPs by SEM at $\times 1000$ (A) and $\times 10,000$ (B) magnification. Panelc C shows EDX analysis and elemental composition (inset of panel C) of synthesized Pd-NPs. 

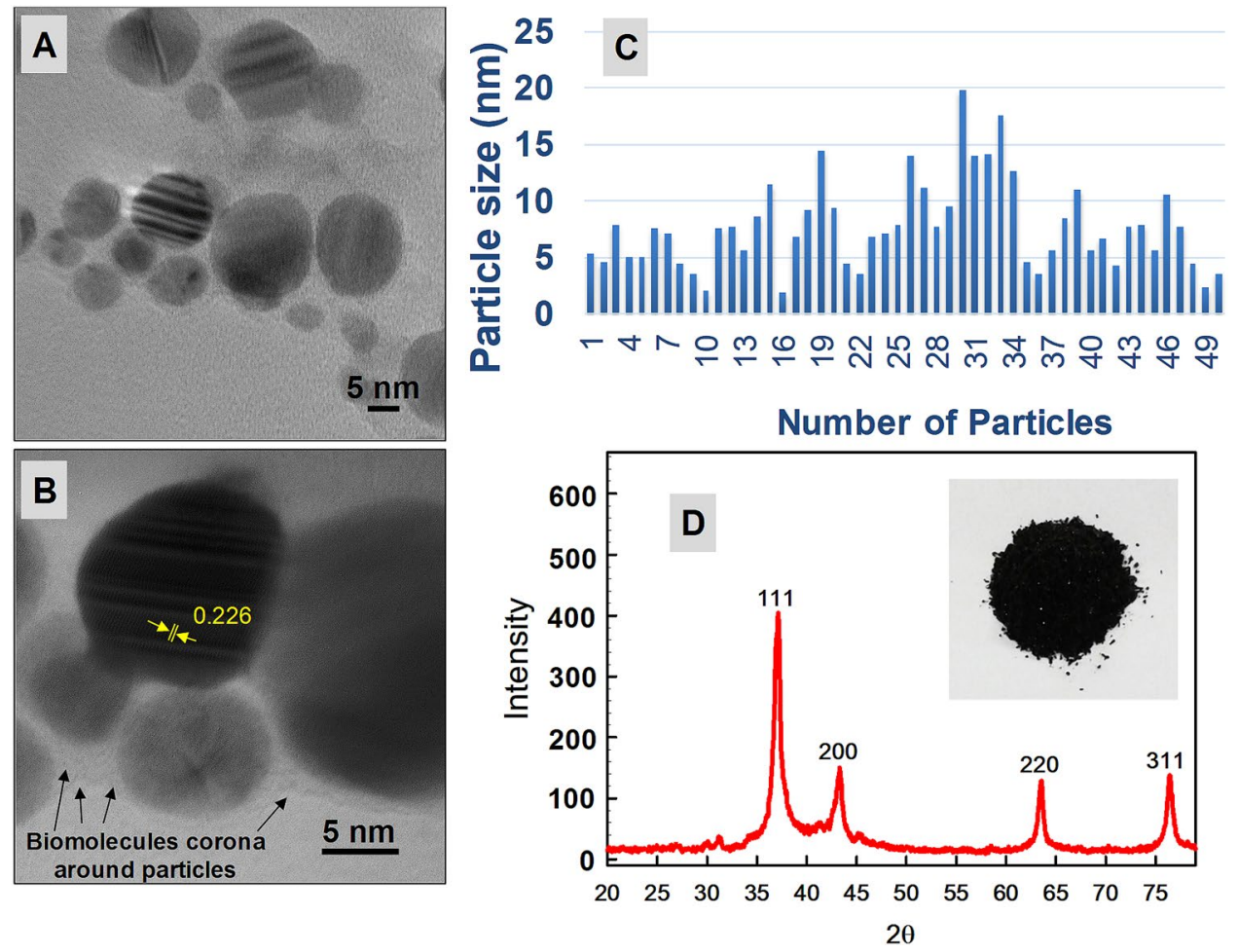

Figure 4. TEM micrographs of PB extract-capped Pd-NPs at direct magnification of $300000 \mathrm{X}$ (panel A) and $\times 800,000$ (panel B). Panel C shows particle size distribution while panel D represent XRD spectra with inset image of Pd-NPs powder.

The role of PB-extract organic molecules in the formation and encapsulation of Pd-NPs was investigated by GC-MS analysis. Various biomolecules were detected in GC-MS and compared with those present in PBextract capped Pd-NPs. GC-MS analysis of the extract revealed the presence of 31 major and minor peaks (Table S2) which were identified as long-chain hydrocarbon acids, esters, and acid chlorides. The major compounds of extract were: 2-palmitoylglycerol (peak area 25.14\%), tricosanoic acid, 2-methoxy-, methyl ester (peak area $19.46 \%$ ), oleic acid glycidyl ester (peak area $6.78+4.91=11.78 \%$ ), cinnamyl linoleate (peak area $4.87 \%$ ), 9,12-Octadecadienoyl chloride (peak area 3.24\%), oleic acid chloride (peak area 2.89\%), methyl oleate (peak area $2.78 \%$ ) and monoolein (1.49\%). The variation in the structure of long-chain hydrocarbons is evident from linear molecules ${ }^{50}$ to cyclic hydrocarbons ${ }^{51}$ with various functional moieties such as $-\mathrm{OH},>\mathrm{C}=\mathrm{O}, \mathrm{C}-\mathrm{O}-\mathrm{C}$, and $-\mathrm{COOH}$ as detected in the present study. Moreover, the single compound could appear as two or more individual peaks. This difference is due to the presence of stereoisomers, identical mass, and functional moieties. Under similar experimental conditions, the GC-MS analysis of Pd-NPs reflected 23 compounds similar to those in the extract (Table 2). The major among them were tricosanoic acid, 2-methoxy-, methyl ester (peak area 31.89\%), 2-palmitoylglycerol (peak area 18.41\%), oleic acid chloride (peak area 14.52\%), oleic acid glycidyl ester (peak area 6.95\%), glycol stearate (peak area 4.14\%), monoolein (peak area 4\%), 9,12-octadecadienoyl chloride (peak area $3.42 \%$ ), and oleic acid, 3-hydroxypropyl ester (peak area 2.76\%). These compounds were involved in the surface capping and stabilization of Pd-NPs. Similar to our study, long-chain aldehydes of various fatty acids such as palmitic, oleic, linoleic, and linolenic acids have been detected in red, green, and brown marine algae ${ }^{52}$. Likewise, an array of long-chain hydrocarbon fatty acids including oleic and palmitic acids were reported as abundant molecules in some species of Chlorophyta and Rhodophyta ${ }^{53}$. In another study, palmitic acid was also reported in brown algae by GC-MS analysis ${ }^{54}$. These type of compounds such as palmitic acid, stearic acid, linolenic acid, tetracosane, tetradecanoic acid, sitosterol etc. have also been detected in plants such as Triticum aestivum $^{55}$, Catharanthus roseus ${ }^{56}$ and Moringa oleifera ${ }^{56}$ by GC-MS.

Identification of bacterial pathogens and drug resistance. S. aureus showed a Gram-positive reaction whereas, E. fergusonii, A. pitti, P. aeruginosa, A. enteropelogenes, and P. mirabilis were found Gram-negative. Molecular identification by partial sequencing of $16 \mathrm{~S}$ rDNA and phylogenetic analysis based on comparison with type strains (Fig. 6) revealed that strain FA-1, FA-5, FA-6, FA-7, FA-8, and FA-9 were S. aureus, E. fergusonii, A. pitti, $P$. aeruginosa, A. enteropelogenes, and P. mirabilis, respectively. The percent similarity of test strains with standard bacteria and obtained accession numbers are presented in Table S3. Antibiotic profiling of test strains showed 69.5, 47.8, 78.2, 86.9, 60.8, and 56.5\% resistance by $S$. aureus, E. fergusonii, A. pitti, P. aeruginosa, A. enteropelogenes, and P. mirabilis towards different classes of $\beta$-lactam and non- $\beta$-lactam antibiotics (Table 3 ). 

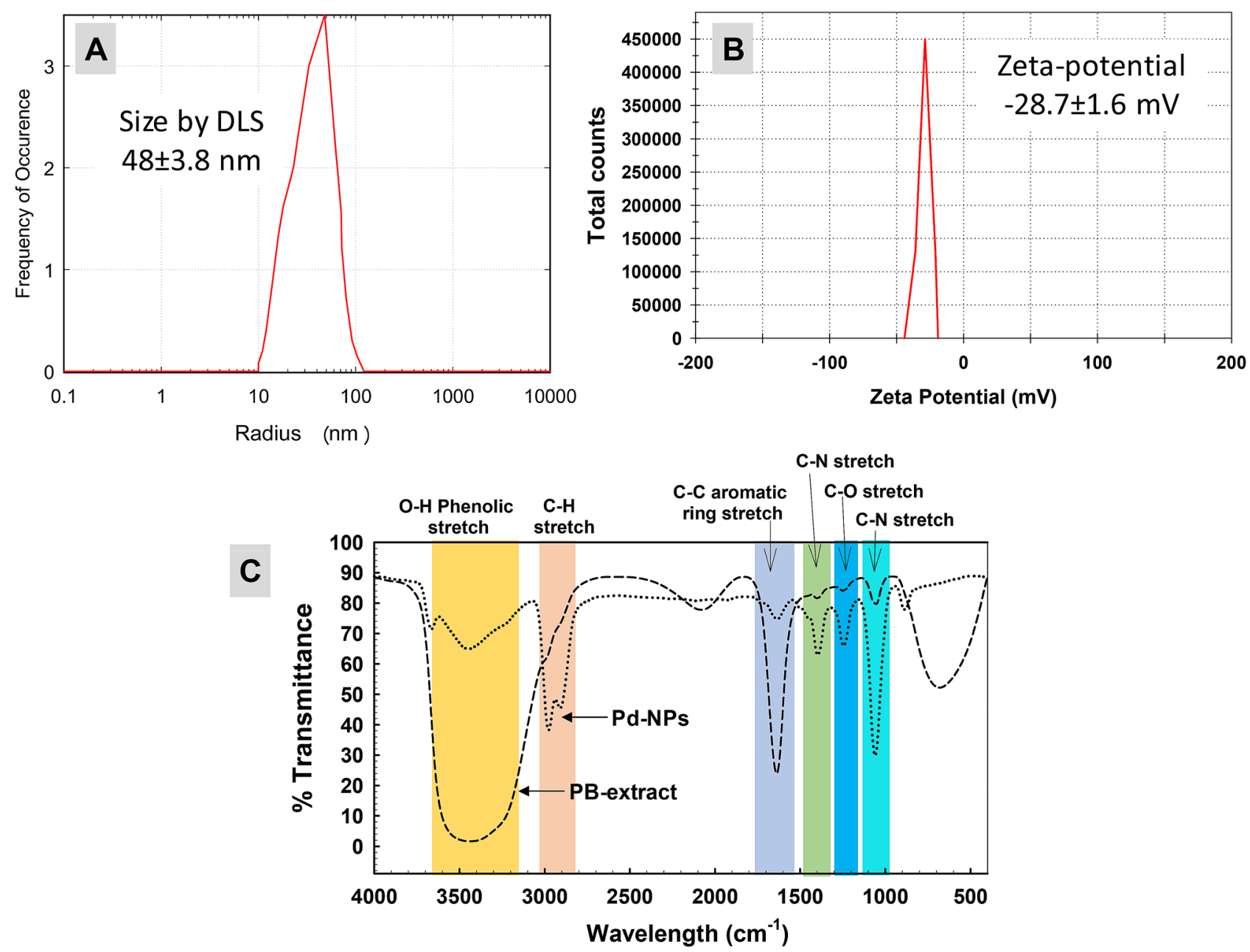

Figure 5. Hydrodynamic size of PB extract-capped Pd-NPs recorded by DLS (panel A) and zeta-potential (panel B). Panel C shows comparative analysis of FT-IR spectra of PB extract and Pd-NPs.

\begin{tabular}{|l|l|l|l|}
\hline Functional group vibration & IR signal in PB-extract & IR signal in Pd-NPs & References \\
\hline$-\mathrm{OH}$ phenolic stretch & $3507-3335$ & $3468-3417$ & Bagad and Khan (2015) \\
\hline C-H stretch of aliphatic hydrocarbons & 2986 & 2974 & Ali et al. (2015) \\
\hline C-H stretch & 2086 & - & Paluszkiewicz and Kwiatek (2001) \\
\hline C=C aromatic ring stretch & 1643 & 1637 & Wang et al. (2014) \\
\hline C-N stretch and C-H bending of alkanes & 1402 & 1401 & Balaji et al. (2017) \\
\hline C-O stretch of ring-oxygen & 1247 & 1247 & Bagad and Khan (2015) \\
\hline C-N stretch of aliphatic amines & 1062 & 1059 & Wang et al. (2014) \\
\hline
\end{tabular}

Table 1. FT-IR investigation of functional group signals and bond assignment.

These strains isolated from various sources have also been found drug-resistant to different sets of antibiotics in other studies $^{57-61}$.

Zone of inhibition and MIC of PB-extract capped Pd-NPs. Bacteria were not found sensitive to PBextract, however, the zone of inhibition produced by gentamicin and Pd-NPs were variable among test strains (Table 4). The size of the inhibition zone created by Pd-NPs was higher than positive control for each bacterium. Recently, a similar kind of inhibition zone was produced by Rosmarinus officinalis mediated Pd-NPs on three clinical bacteria Micrococcus luteus, S. aureus, and S. epidermidis as compared to the positive control, ciprofloxacin $^{62}$. MIC was variable i.e. $125 \mu \mathrm{g} / \mathrm{mL}$ for S. aureus and P. mirabilis, whereas, $62.5 \mu \mathrm{g} / \mathrm{mL}$ for other strains (Table 5). In a similar study, the MIC of Pd-NPs (prepared by Sapium sebiferum leaf extract) for S. aureus, P. aeruginosa, and Bacillus subtilis was measured as $45.4,103.5$, and $71.2 \mu \mathrm{g} / \mathrm{mL}^{63}$ which is in fair agreement with our results. 


\begin{tabular}{|l|l|l|l|l|l|}
\hline Peak & Peak area (\%) & Retention time & Compound & Molecular formula & Molecular weight \\
\hline 1 & 0.59 & 12.235 & 12-Docosenol, TMS & $\mathrm{C}_{25} \mathrm{H}_{52} \mathrm{OSi}$ & 396 \\
\hline 2 & 0.78 & 14.985 & Isobutyl Phthalate & $\mathrm{C}_{16} \mathrm{H}_{22} \mathrm{O}_{4}$ & 278 \\
\hline 3 & 1.14 & 17.186 & 2,4-di-tert-butylphenol & $\mathrm{C}_{14} \mathrm{H}_{22} \mathrm{O}$ & 206 \\
\hline 4 & 0.76 & 18.562 & Ethylene undecane dicarboxylate & $\mathrm{C}_{15} \mathrm{H}_{26} \mathrm{O}_{4}$ & 270 \\
\hline 5 & 0.55 & 21.154 & Methyl oleate & $\mathrm{C}_{19} \mathrm{H}_{36} \mathrm{O}_{2}$ & 296 \\
\hline 6 & 18.41 & 21.569 & 2-palmitoylglycerol & $\mathrm{C}_{19} \mathrm{H}_{38} \mathrm{O}_{4}$ & 330 \\
\hline 7 & 0.64 & 22.056 & Palmitic acid, trimethylsilyl ester & $\mathrm{C}_{19} \mathrm{H}_{40} \mathrm{O}_{2} \mathrm{Si}_{1}$ & 328 \\
\hline 8 & 0.49 & 22.478 & Hexadecanoic acid, dimethyl(isopropyl)silyl ester & $\mathrm{C}_{21} \mathrm{H}_{44} \mathrm{O}_{2} \mathrm{Si}$ & 356 \\
\hline 9 & 1.14 & 22.786 & Monoolein & $\mathrm{C}_{21} \mathrm{H}_{40} \mathrm{O}_{4}$ & 356 \\
\hline 10 & 0.89 & 22.569 & Palmitic Acid Glycidyl Ester & $\mathrm{C}_{19} \mathrm{H}_{36} \mathrm{O}_{3}$ & 312 \\
\hline 11 & 0.72 & 22.621 & 2,5 -Di (Trifluoromethyl) Benzoic acid, Dodecyl & $\mathrm{C}_{21} \mathrm{H}_{28} \mathrm{~F}_{6} \mathrm{O}_{2}$ & 426 \\
\hline 12 & 14.52 & 22.814 & Ester & $\mathrm{C}_{18} \mathrm{H}_{33} \mathrm{ClO}_{3}$ & 300 \\
\hline 13 & 31.89 & 22.874 & Tric acid chloride & $\mathrm{C}_{25} \mathrm{H}_{50} \mathrm{O}_{3}$ & 398 \\
\hline 14 & 6.95 & 23.012 & Oleic acid glycidyl ester & $\mathrm{C}_{21} \mathrm{H}_{38} \mathrm{O}_{3}$ & 338 \\
\hline 15 & 4.14 & 23.478 & Glycol stearate & $\mathrm{C}_{20} \mathrm{H}_{40} \mathrm{O}_{3}$ & 328 \\
\hline 16 & 1.31 & 23.511 & Palmitic acid glycidyl ester & $\mathrm{C}_{19} \mathrm{H}_{36} \mathrm{O}_{3}$ & 312 \\
\hline 17 & 1.14 & 23.596 & Cannabidiol & $\mathrm{C}_{21} \mathrm{H}_{30} \mathrm{O}_{2}$ & 314 \\
\hline 18 & 2.18 & 24.104 & Bis(2-ethylhexyl) phthalate & $\mathrm{C}_{24} \mathrm{H}_{38} \mathrm{O}_{4}$ & 390 \\
\hline 19 & 3.42 & 24.314 & 9,12 -Octadecadienoyl chloride & $\mathrm{C}_{18} \mathrm{H}_{31} \mathrm{ClO}_{2}$ & 298 \\
\hline 20 & 2.86 & 24.524 & Monoolein & $\mathrm{C}_{21} \mathrm{H}_{40} \mathrm{O}_{4}$ & 356 \\
\hline 21 & 0.93 & 24.789 & Palmitic Acid Glycidyl Ester & $\mathrm{C}_{19} \mathrm{H}_{36} \mathrm{O}_{3}$ & 312 \\
\hline 22 & 2.76 & 25.542 & Oleic acid, 3-hydroxypropyl ester & $\mathrm{C}_{21} \mathrm{H}_{40} \mathrm{O}_{3}$ & 340 \\
\hline 23 & 1.79 & 26.142 & Fumaric acid, decyl 2-heptyl ester & $\mathrm{C}_{21} \mathrm{H}_{38} \mathrm{O}_{4}$ & 354 \\
\hline & 100 & & & & \\
\hline
\end{tabular}

Table 2. GC-MS analysis of PB extract mediated Pd-NPs.

Pd-NPs concentration-dependent growth of isolates and membrane destruction. When the exposure of Pd-NPs was increased from $7.81 \mu \mathrm{g} / \mathrm{mL}$ at a geometrical progression with a common ratio of 3 up to $250 \mu \mathrm{g} / \mathrm{mL}$, the number of viable cells and thus CFU/mL at logarithmic scale was reduced (Fig. 7A). A $\leq 50 \%$ reduction in cell population was observed at $31.25 \mu \mathrm{g} / \mathrm{mL}$ for E. fergusonii, S. aureus, and A. pitti, $62.5 \mu \mathrm{g} / \mathrm{mL}$ for A. enteropelogenes and P. aeruginosa, and $125 \mu \mathrm{g} / \mathrm{mL}$ for $P$. mirabilis. Regression analysis between concentrations of Pd-NPs versus average $\log _{10} \mathrm{CFU} / \mathrm{mL}$ resulted in an $\mathrm{R}^{2}$ value of 0.70 which shows a negative correlation (Fig. 7B). So far no study has reported the CFU-based bacterial inhibition by algal mediated Pd-NPs. Progressive damage to the bacterial cell membrane permeability was also noticed (Fig. 7C). PI clearly distinguishes between live and dead cell due to its ability to permeate only the membrane damaged cells followed by binding to DNA and fluorescence emission $(\lambda \mathrm{exc}=532 \mathrm{~nm})$. Cells exposed to low concentration of Pd-NPs $(7.81-15.62 \mu \mathrm{g} / \mathrm{mL})$ showed less number of membrane altered cells. However, a significant $(P \leq 0.05$ or 0.01$)$ number of membrane compromised cells at a higher dose rate suggests substantial interaction of Pd-NPs with the bacterial cell membrane.

Biofilm inhibition of isolates by PB-capped Pd-NPs. Biofilm formation of test strains was first compared with biofilm positive strains and it was found that all the MDR strains could form the biofilm (Figure S1). PB-extract capped Pd-NPs significantly reduced the biofilm formation in a dose-related fashion as compared to control (Fig. 8). For the sake of comparison, at $31.25 \mu \mathrm{g} / \mathrm{mL}$ concentration, the order of biofilm formation was: P. mirabilis $(36.9 \%)>S$. aureus $(27.2 \%)>A$. pitti $(21.36 \%)$, P. aeruginosa $(15.63 \%)>$ E. fergusonii $(12.36 \%)>A$. enteropelogenes (8.9\%). At $125 \mu \mathrm{g} / \mathrm{mL}$, Pd-NPs completely abolished the biofilm formation irrespective of the test strain. Biofilms play a very critical role in successfully producing virulence factors that are controlled by a feed-forward control loop of quorum sensing signals (production of acyl-homoserine lactones) and thus a drug-resistant infection establishes ${ }^{64}$. To date, no antibiofilm study of marine algae-mediated Pd-NPs has been reported, however, a nanocomposite of Pd-graphene oxide showed a reduction in biofilm formation of Bacillus subtilis, E. coli, P. aeruginosa, Klebsiella pneumoniae by microdilution method ${ }^{65}$. Besides, extra polymeric substance (EPS), biofilms also contain lipids, proteins, and DNA that resist higher concentrations of antibiotics and compromise the host immune system.

The smaller size Pd-NPs synthesized in our study with a large surface area and biologically active capping material could serve as an alternative or supplement to antibiotics effectively inhibiting the growth of pathogens. While interacting with bacterial cells, PB-extract capped Pd-NPs can exert toxic impacts on bacterial growth and metabolism by direct reactions including the following: (i) attachment to peptidoglycan (PG; a polymer of sugars and amino acids around cell membrane) layer due to the linkage between free amino groups $\left(-\mathrm{NH}_{2}\right)$ and hydroxyl $(-\mathrm{OH})$, carbonyl $(>\mathrm{C}=\mathrm{O})$, epoxide or ester groups of biomolecules present in $\mathrm{PB}$-extract. This 


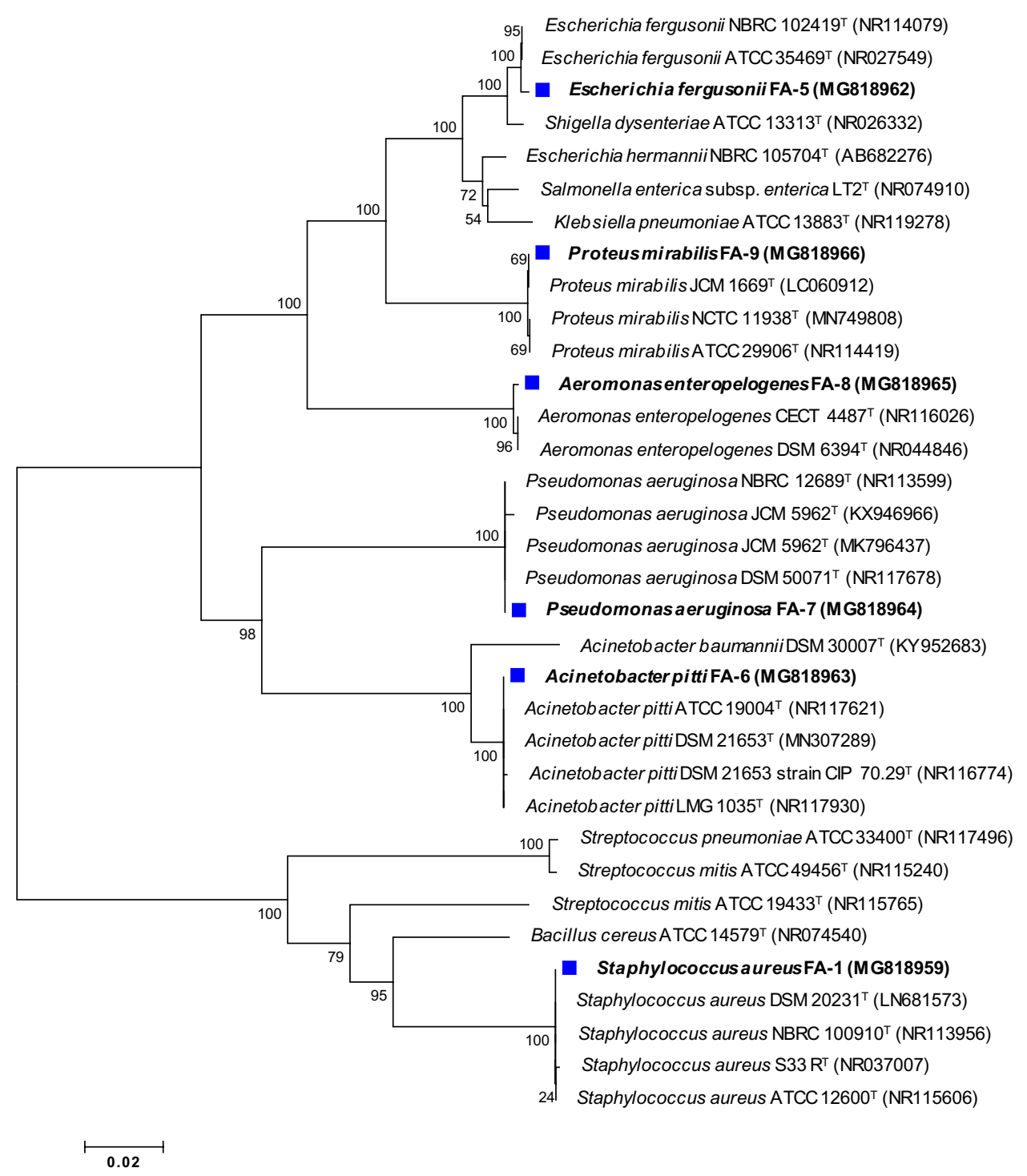

Figure 6. Unrooted neighbour-joined phylogenetic tree of isolated bacteria. The tree was constructed based on 16S rRNA partial gene sequence of bacterial isolates (marked with blue square) and closely related type species derived using NCBI BLAST search tool. Sequences were aligned using Clustal W sequence alignment tool in MEGA 7.0 software. The GenBank accession numbers of isolates and closely related species are placed in parenthesis. Bootstrap percentage values as obtained from 1000 replications of the data set are given at tree's nodes. The scale bar corresponds to the mean number of nucleotide substitutions per site.

binding can also facilitate the inside entry of Pd-NPs into periplasmic space, (ii) creation of new pores in the cell membrane by physical interaction with phospholipids and membrane lipid peroxidation and thus altering the membrane permeability, (iii) inactivation of cellular enzymes, and (iv) destruction of biofilm formation by negatively charged EPS mediated mobilization of positively charged Pd-NPs or $\mathrm{Pd}^{2+}$ ions (released from Pd-NPs) to biofilms as depicted in (Fig. 9). Indirectly, encounter and binding of -SH groups of proteins with Pd-NPs can trigger a modification of $\mathrm{PO}_{4}^{-}$efflux system leading to cell membrane exfoliation from cytoplasm, intracellular oxidative stress, dysfunction DNA replication system, and leakage of cell content.

In vitro cancer cell cytotoxicity and apoptosis. MTT assay quantifies the production of cellular oxidoreductase enzymes (NADPH mediated) following the reduction of MTT stain and thus reveals the metabolic activity of cells. These enzymes reduce the MTT to an insoluble form of formazan. Whereas, NRU uptake assay measures the influx of neutral red into lysosomes of metabolically active cells. The data exhibited a dose-dependent significant $(P \leq 0.05$ and 0.01$)$ reduction of MCF-7 cellular activity and cell viability was found decreased as compared to control cells (untreated) (Fig. 10A). At 62.5 and $125 \mu \mathrm{g} / \mathrm{mL}$ of Pd-NPs, the percent reduction in viable cells was found as $38 \%$ and $53 \%$ by MTT assay, and $32 \%$ and $45 \%$ by NRU assay. This data clearly shows lysosomal toxicity and the destruction of cellular metabolism by Pd-NPs. The cytotoxic activity of green Pd-NPs to human leukemia cancer 


\begin{tabular}{|c|c|c|c|c|c|c|c|c|c|}
\hline \multirow{2}{*}{\multicolumn{3}{|c|}{ Antibiotics }} & \multirow{3}{*}{$\begin{array}{l}\text { Disc potency } \\
(\mu \mathrm{g} / \mathrm{disc})\end{array}$} & \multicolumn{6}{|c|}{ Zone of inhibition (mm) } \\
\hline & & & & \multirow[t]{2}{*}{ S. aureus FA-1 } & \multirow[t]{2}{*}{$\begin{array}{l}\text { E. fergusonii } \\
\text { FA-5 }\end{array}$} & \multirow[t]{2}{*}{ A. pittii FA-6 } & \multirow[t]{2}{*}{$\begin{array}{l}\text { P. aeruginosa } \\
\text { FA-7 }\end{array}$} & \multirow[t]{2}{*}{$\begin{array}{l}\text { A. } \\
\text { enteropelogenes } \\
\text { FA-8 }\end{array}$} & \multirow[t]{2}{*}{$\begin{array}{l}\text { P. mirabilis } \\
\text { FA-9 }\end{array}$} \\
\hline & $\begin{array}{l}\text { Antimicrobial } \\
\text { class }\end{array}$ & Antibiotic & & & & & & & \\
\hline \multirow{10}{*}{$\begin{array}{l}\beta \text {-lactam anti- } \\
\text { biotics }\end{array}$} & \multirow{6}{*}{ Cephems } & Cefa-sulbactum & $75 / 10$ & $19^{\mathrm{S}}$ & $20^{\mathrm{S}}$ & $13^{\mathrm{R}}$ & $15^{\mathrm{R}}$ & $19^{\mathrm{S}}$ & $12^{\mathrm{R}}$ \\
\hline & & Cefoperazone & 75 & $12^{\mathrm{R}}$ & $15^{\mathrm{R}}$ & $17^{\mathrm{I}}$ & $14^{\mathrm{R}}$ & $13^{\mathrm{R}}$ & $14^{\mathrm{R}}$ \\
\hline & & $\begin{array}{l}\text { Cefepime tazo- } \\
\text { bactam }\end{array}$ & $30 / 10$ & $19^{\mathrm{S}}$ & $18^{\mathrm{S}}$ & $14^{\mathrm{R}}$ & $18^{\mathrm{S}}$ & $14^{\mathrm{R}}$ & $11^{\mathrm{R}}$ \\
\hline & & Cefotaxime & 30 & $13^{\mathrm{R}}$ & $17^{\mathrm{R}}$ & $13^{\mathrm{R}}$ & $13^{\mathrm{R}}$ & $17^{\mathrm{S}}$ & $13^{\mathrm{R}}$ \\
\hline & & Ceftazidime & 30 & $12^{\mathrm{R}}$ & $16^{\mathrm{R}}$ & $11^{\mathrm{R}}$ & $15^{\mathrm{I}}$ & $13^{\mathrm{R}}$ & $11^{\mathrm{R}}$ \\
\hline & & Cefepime & 30 & $12^{\mathrm{R}}$ & $17^{\mathrm{R}}$ & $16^{\mathrm{I}}$ & $13^{\mathrm{R}}$ & $27^{\mathrm{S}}$ & $18^{\mathrm{I}}$ \\
\hline & Carbapenem & Imipenem & 10 & $16^{\mathrm{I}}$ & $21^{\mathrm{S}}$ & $13^{\mathrm{R}}$ & $13^{\mathrm{R}}$ & $22^{\mathrm{S}}$ & $20^{\mathrm{S}}$ \\
\hline & Monobactam & Aztreonam & 30 & $18^{\mathrm{I}}$ & $16^{\mathrm{R}}$ & $11^{\mathrm{R}}$ & $12^{\mathrm{R}}$ & $20^{\mathrm{S}}$ & $17^{1}$ \\
\hline & $\begin{array}{l}\text { Penicillin-like } \\
\text { antibiotics }\end{array}$ & Amoxicillin & 10 & $0^{\mathrm{R}}$ & $15^{\mathrm{I}}$ & $10^{\mathrm{R}}$ & $11^{\mathrm{R}}$ & $11^{\mathrm{R}}$ & $10^{\mathrm{R}}$ \\
\hline & $\begin{array}{l}\text { Penicillin beta- } \\
\text { lactam antibiotic }\end{array}$ & Oxacillin & 5 & $14^{\mathrm{R}}$ & $17^{1}$ & $12^{\mathrm{R}}$ & $0^{\mathrm{R}}$ & $0^{\mathrm{R}}$ & $11^{\mathrm{R}}$ \\
\hline \multirow{14}{*}{$\begin{array}{l}\text { Non } \beta \text {-lactam } \\
\text { antibiotics }\end{array}$} & Sulfonamides & Co-trimoxazole & 25 & $0^{\mathrm{R}}$ & $15^{\mathrm{I}}$ & $16^{1}$ & $12^{\mathrm{R}}$ & $0^{\mathrm{R}}$ & $10^{\mathrm{R}}$ \\
\hline & \multirow{4}{*}{$\begin{array}{l}\text { Fluoroquinolo- } \\
\text { nes }\end{array}$} & Ciprofloxacin & 5 & $0^{\mathrm{R}}$ & $13^{\mathrm{R}}$ & $12^{\mathrm{R}}$ & $10^{\mathrm{R}}$ & $10^{\mathrm{R}}$ & $15^{\mathrm{I}}$ \\
\hline & & Norfloxacin & 10 & $18^{\mathrm{S}}$ & $14^{\mathrm{R}}$ & $0^{\mathrm{R}}$ & $0^{\mathrm{R}}$ & $10^{\mathrm{R}}$ & $19^{\mathrm{S}}$ \\
\hline & & \begin{tabular}{|l|} 
Gatifloxacin \\
\end{tabular} & 5 & $0^{\mathrm{R}}$ & $12^{\mathrm{R}}$ & $10^{\mathrm{R}}$ & $0^{\mathrm{R}}$ & $17^{1}$ & $10^{\mathrm{R}}$ \\
\hline & & Ofloxacin & 5 & $0^{\mathrm{R}}$ & $0^{\mathrm{R}}$ & $0^{\mathrm{R}}$ & $11^{\mathrm{R}}$ & $12^{\mathrm{R}}$ & $10^{\mathrm{R}}$ \\
\hline & \multirow{3}{*}{$\begin{array}{l}\text { Aminoglyco- } \\
\text { sides }\end{array}$} & Gentamicin & 10 & $13^{\mathrm{R}}$ & $15^{\mathrm{S}}$ & $19^{\mathrm{S}}$ & $17^{\mathrm{S}}$ & $20^{\mathrm{S}}$ & $18^{\mathrm{S}}$ \\
\hline & & Amikacin & 30 & $14^{\mathrm{R}}$ & $14^{\mathrm{R}}$ & $12^{\mathrm{R}}$ & $12^{\mathrm{R}}$ & $10^{\mathrm{R}}$ & $16^{\mathrm{I}}$ \\
\hline & & Tobramycin & 10 & $14^{\mathrm{R}}$ & $14^{\mathrm{I}}$ & $15^{\mathrm{I}}$ & $12^{\mathrm{R}}$ & $0^{\mathrm{R}}$ & $17^{1}$ \\
\hline & Macrolides & Erythromycin & 15 & $0^{\mathrm{R}}$ & $11^{\mathrm{R}}$ & $0^{\mathrm{R}}$ & $0^{\mathrm{R}}$ & $15^{1}$ & $0^{\mathrm{R}}$ \\
\hline & Ansamycin & Rifampicin & 5 & $23^{1}$ & $18^{\mathrm{I}}$ & $10^{\mathrm{R}}$ & $0^{\mathrm{R}}$ & $16^{\mathrm{I}}$ & $0^{\mathrm{R}}$ \\
\hline & Tetracycline & Tetracycline & 30 & $17^{1}$ & $14^{\mathrm{I}}$ & $11^{\mathrm{R}}$ & $10^{\mathrm{R}}$ & $10^{\mathrm{R}}$ & $17^{\mathrm{I}}$ \\
\hline & \begin{tabular}{|l|} 
Quinolones \\
\end{tabular} & Nalidixic acid & 30 & $13^{\mathrm{R}}$ & $15^{\mathrm{I}}$ & $10^{\mathrm{R}}$ & $12^{\mathrm{R}}$ & $0^{\mathrm{R}}$ & $10^{\mathrm{R}}$ \\
\hline & Phenicols & $\begin{array}{l}\text { Chlorampheni- } \\
\text { col }\end{array}$ & 30 & $0^{\mathrm{R}}$ & $15^{1}$ & $0^{\mathrm{R}}$ & $11^{\mathrm{R}}$ & $0^{\mathrm{R}}$ & $16^{\mathrm{I}}$ \\
\hline & \% Resistance & & & 69.5 & 47.8 & 78.2 & 86.9 & 60.8 & 56.5 \\
\hline
\end{tabular}

Table 3. Antibiotic resistance profile of bacterial isolates. $S$ sensitive, $I$ intermediate, $R$ resistant based on Clinical and Laboratory Standards Institute (CLSI) and the European Committee for Antimicrobial Susceptibility Testing (EUCAST) guidelines. Percent (\%) resistance was calculated using following formula $=$ total no. of antibiotics marked with $\mathrm{R}$ for each strain/total no. of test antibiotics $\times 100$.

\begin{tabular}{|c|c|c|c|}
\hline \multirow[b]{2}{*}{ Bacterial isolates } & \multicolumn{3}{|l|}{ Zone of inhibition (mm) } \\
\hline & Negative control (PB extract) & $\begin{array}{l}\text { Positive control (Gentamicin } \\
10 \mu \mathrm{g} / \text { disc) }\end{array}$ & $\begin{array}{l}\text { PB-capped Pd-NPs }(100 \mu \mathrm{L} / \text { well } \\
\text { from stock of } 1 \mathrm{mg} / \mathrm{mL})\end{array}$ \\
\hline Staphylococcus aureus & $0 \pm 0$ & $13.3 \pm 0.47$ & $18.3 \pm 1.24$ \\
\hline Escherichia fergusonii & $0 \pm 0$ & $15.3 \pm 0.47$ & $20.0 \pm 0.81$ \\
\hline Acinetobacter pittii & $0 \pm 0$ & $19.0 \pm 0.81$ & $23.0 \pm 0.8$ \\
\hline Pseudomonas aeruginosa & $0 \pm 0$ & $15.6 \pm 0.94$ & $21.3 \pm 0.47$ \\
\hline Aeromonas enteropelogenes & $0 \pm 0$ & $20.6 \pm 0.9$ & $19.3 \pm 0.5$ \\
\hline Proteus mirabilis & $0 \pm 0$ & $18.3 \pm 0.47$ & $23.0 \pm 1.6$ \\
\hline
\end{tabular}

Table 4. Antibacterial activity of PB-capped Pd-NPs by well diffusion assay. 


\begin{tabular}{|l|l|}
\hline Bacterial isolates & MIC $(\mu \mathrm{g} / \mathrm{mL})$ \\
\hline Staphylococcus aureus & 125 \\
\hline Escherichia fergusonii & 62.5 \\
\hline Acinetobacter pittii & 62.5 \\
\hline Pseudomonas aeruginosa & 62.5 \\
\hline Aeromonas enteropelogenes & 62.5 \\
\hline Proteus mirabilis & 125 \\
\hline
\end{tabular}

Table 5. Minimum inhibitory concentration (MIC) of PB-capped Pd-NPs.
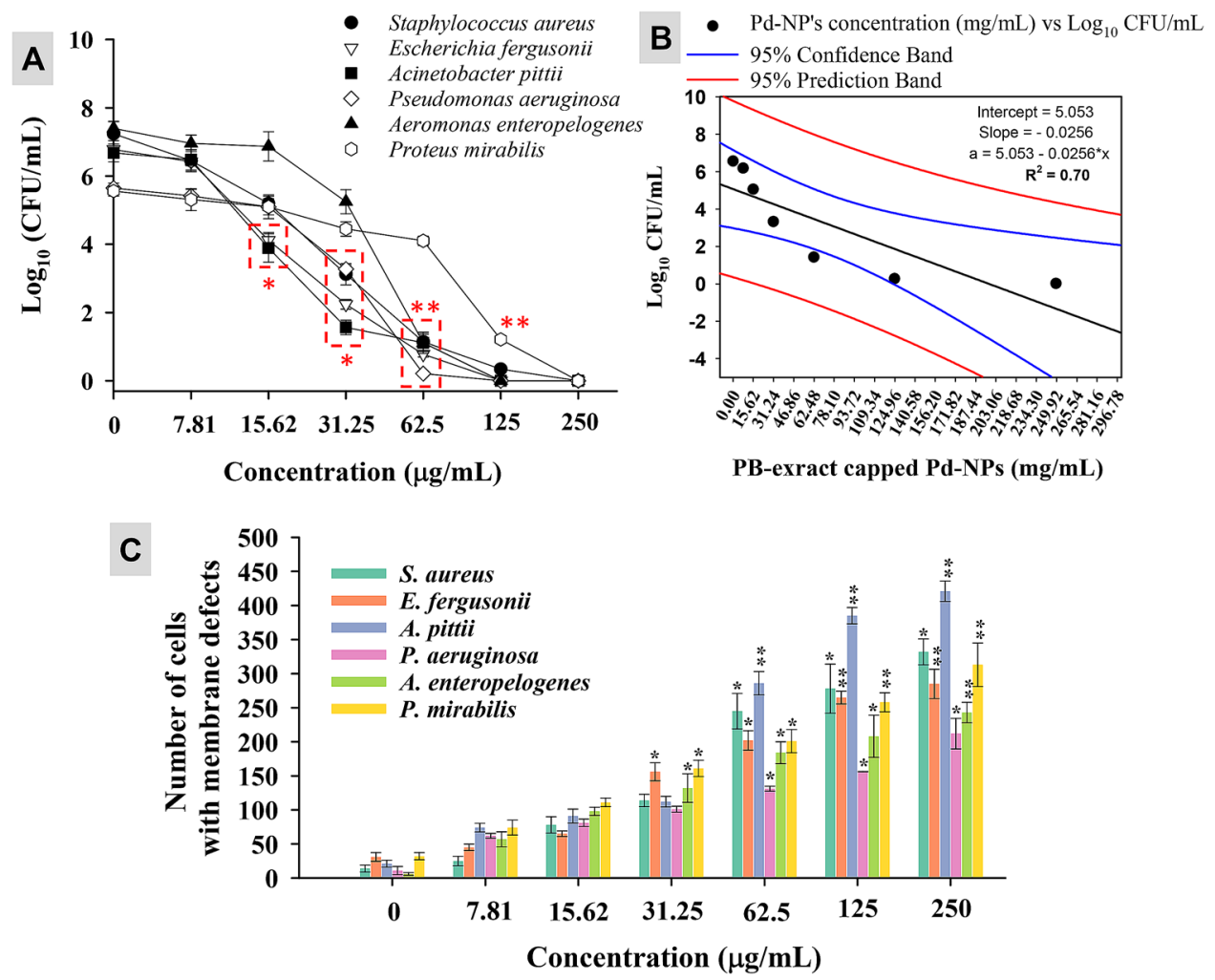

Figure 7. PB extract-capped Pd-NPs concentration $(7.81-250 \mu \mathrm{g} / \mathrm{mL})$ dependent CFU count of bacterial cultures (panel A), regression analysis of average $\mathrm{CFU} / \mathrm{mL}$ of all strains versus $\mathrm{PB}$ extract-capped Pd-NPs concentration (panel B), and impact of PB extract-capped Pd-NPs on cell membrane permeability (panel C). Data represents mean values of three independent replicates and error bars represent standard deviation (S.D.). ${ }^{\star} P \leq 0.05$ and ${ }^{* *} P \leq 0.01$ based on student's t-test.

cell lines has been suggested due to the physicochemical interaction of Pd-NPs with DNA, proteins, phosphate groups, cell cycle arrest, free radical formation, and leakage of lactate dehydrogenase ${ }^{66}$. Under NPs stress, cancer cells regulate gene expression to circumvent cellular disruption thereby restoring signaling and cell cycle. In current study, two concentrations $(62.5$ and $125 \mu \mathrm{g} / \mathrm{mL})$ of Pd-NPs induced expression of apoptotic marker genes in folds in the following order: $p 53$ (4.5-folds) $>$ caspase- 3 ( 2.5 -folds) $>$ bax $(2$-folds $)>$ caspase- 9 ( 1.5 -fold) at $62.5 \mu \mathrm{g}$ Pd-NPs/mL and $p 53$ (5.5-folds) > bax (3.5-folds) >caspase-3 (3-folds) $>$ caspase-9 (2-folds) at $125 \mu \mathrm{g}$ Pd-NPs/mL (Fig. $10 \mathrm{~B}-\mathrm{E}$ ). The enhanced expression of $p 53 \mathrm{mRNA}$ transcripts suggests multiple targets of Pd-NPs in MCF-7 cells including generation of oxidative stress, dysfunction of mitochondria, aberration on cell cycle, and apopto- 

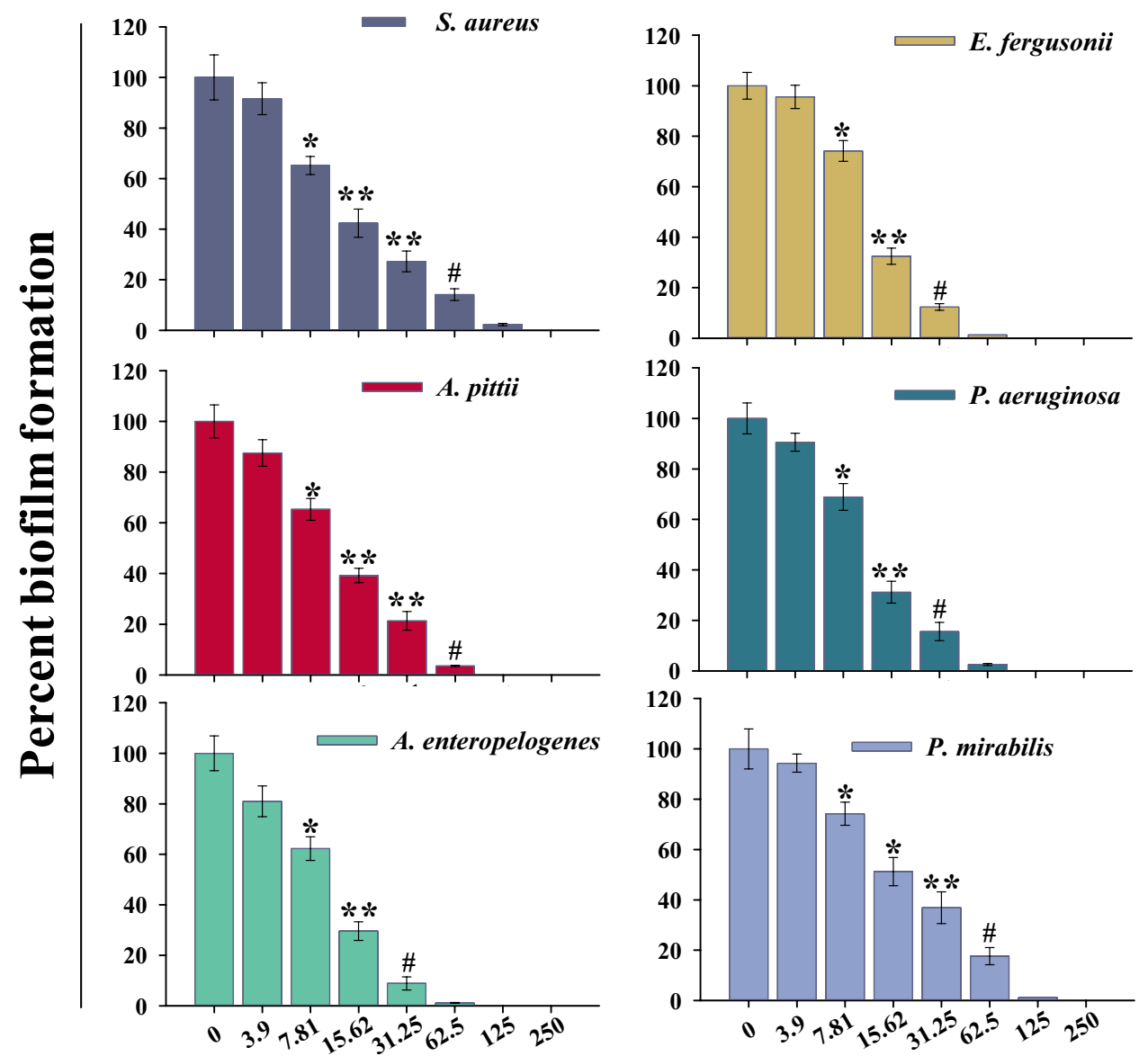

\section{PB-capped Pd-NPs $(\mu \mathrm{g} / \mathrm{mL})$}

Figure 8. PB extract-capped Pd-NPs $(3.9-250 \mu \mathrm{g} / \mathrm{mL})$ dependent biofilm formation by bacterial cultures over respective untreated controls. Data represents mean values of three independent replicates and error bars represent standard deviation (S.D.). ${ }^{\star} P \leq 0.05,{ }^{* *} P \leq 0.01$, $\# P \leq 0.001$ based on student's t-test.

sis. Similarly, bax is a well-known apoptosis inducer. Higher expression of two of the major caspases (caspase-9 and caspase-3) emphasizes the fragmentation of nuclear material and suggests the role of mitochondria in $p 53$ apoptosis. Moreover, higher expression of $p 53$ enhances the transcription of bax, caspase- 9 , and caspase- 3 as proapoptotic genes ${ }^{67}$. Cancer cell death mediated by PB-extract capped Pd-NPs is schematically presented in Fig. 9.

In a comparative analysis, $\mathrm{PB}$-extract capped Pd-NPs were found more active against pathogenic biofilms and breast cancer cells as compared to bare-PdNPs Fig. 11. The enhanced in vitro clinical performance of PB-extract capped Pd-NPs is possibly due to the capping of P. boryana biomolecules. The apparent difference in antibiofilm and anticancer potential of two species of Pd-NPs probably arises as a result of bioactive corona of PB extract biomolecules and functional groups around Pd-NPs which might help in the enhanced uptake of PB-capped Pd-NPs by bacterial and cancer cells (primary factor) which in turn results in Pd-NPs toxicity (secondary factor). Similar kind of results have been reported in two other studies where green synthesized $\alpha-\mathrm{Fe}_{2} \mathrm{O}_{3}$ and $\mathrm{CuO}$ NPs were compared with uncapped $\alpha-\mathrm{Fe}_{2} \mathrm{O}_{3}{ }^{68}$ and $\mathrm{CuO} \mathrm{NPs}{ }^{69}$. Results showed substantial reduction of cell viability and biofilm formation by E. coli. S. aureus, and P. aeruginosa.

\section{Conclusion}

The current study is perhaps the first study which explored the constituents of marine brown seaweed P. boryana by FT-IR and GC-MS analysis and proved their role in bio-reduction and bio-capping of Pd-NPs. The green synthesized Pd-NPs were fairly small in size, spherical and crystalline which were biologically effective in the range of $31.25-125 \mu \mathrm{g} / \mathrm{mL}$ against six MDR bacteria and human breast cancer MCF-7 cell line. The antibiofilm and anticancer efficiency of PB-extract capped Pd-NPs was higher than the uncapped or bare-PdNPs. A very few algae have been used for Pd-NPs fabrication but lack the detailed exploration of capping and assessment of biomedical potential. The developed synthesis method is cost-effective, green, and can be easily scaled up. Our green Pd-NPs are further warranted for in vivo research in an animal model to determine their safety to humans. However, the PB-extract capped Pd-NPs can be applied for the coating of medical appliances to control the resistant bacterial infections thus safeguarding the health of patients. 


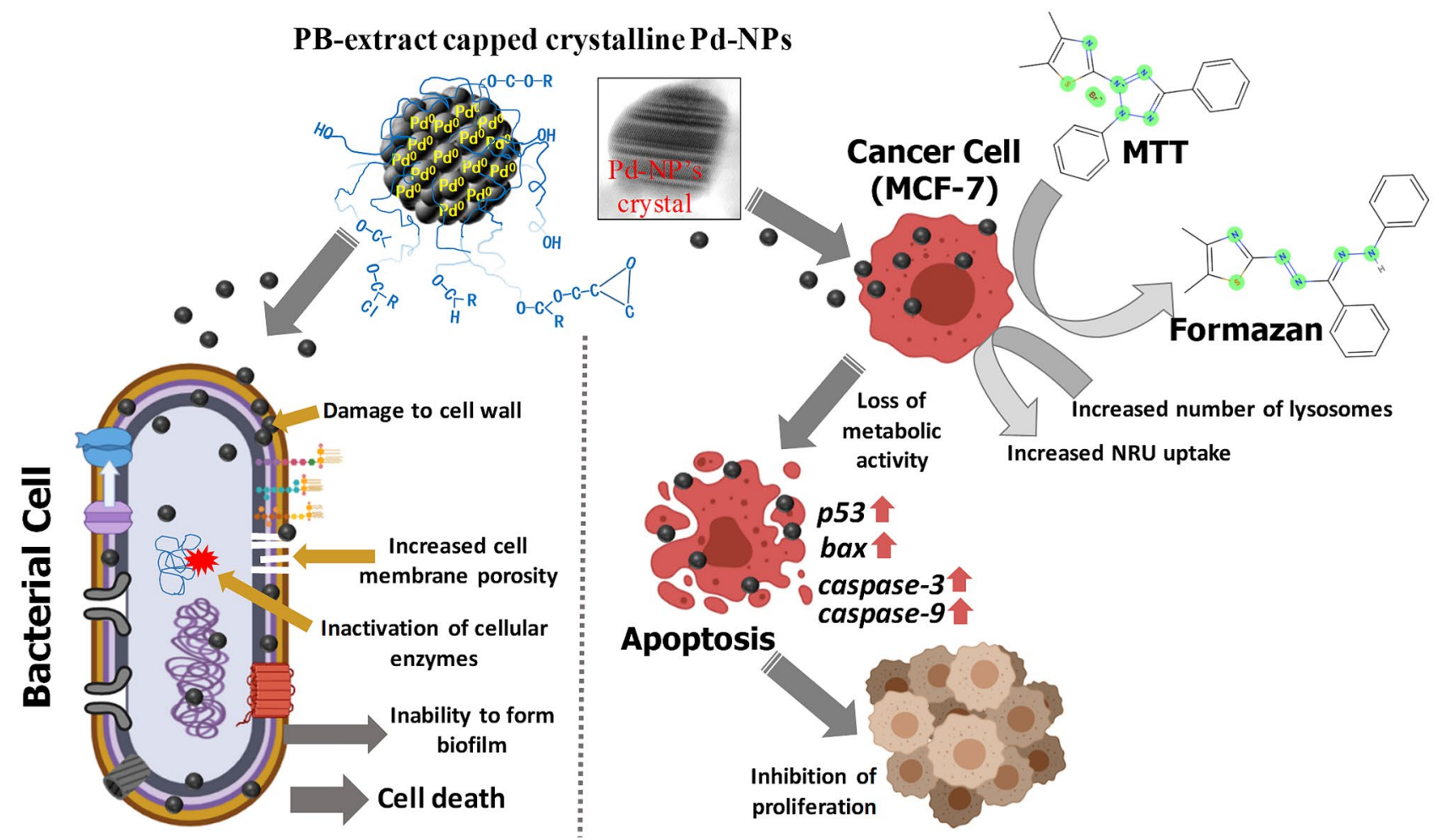

Figure 9. Schematic representation of PB-extract capped Pd-NPs mediated bacterial and cancer cell death.
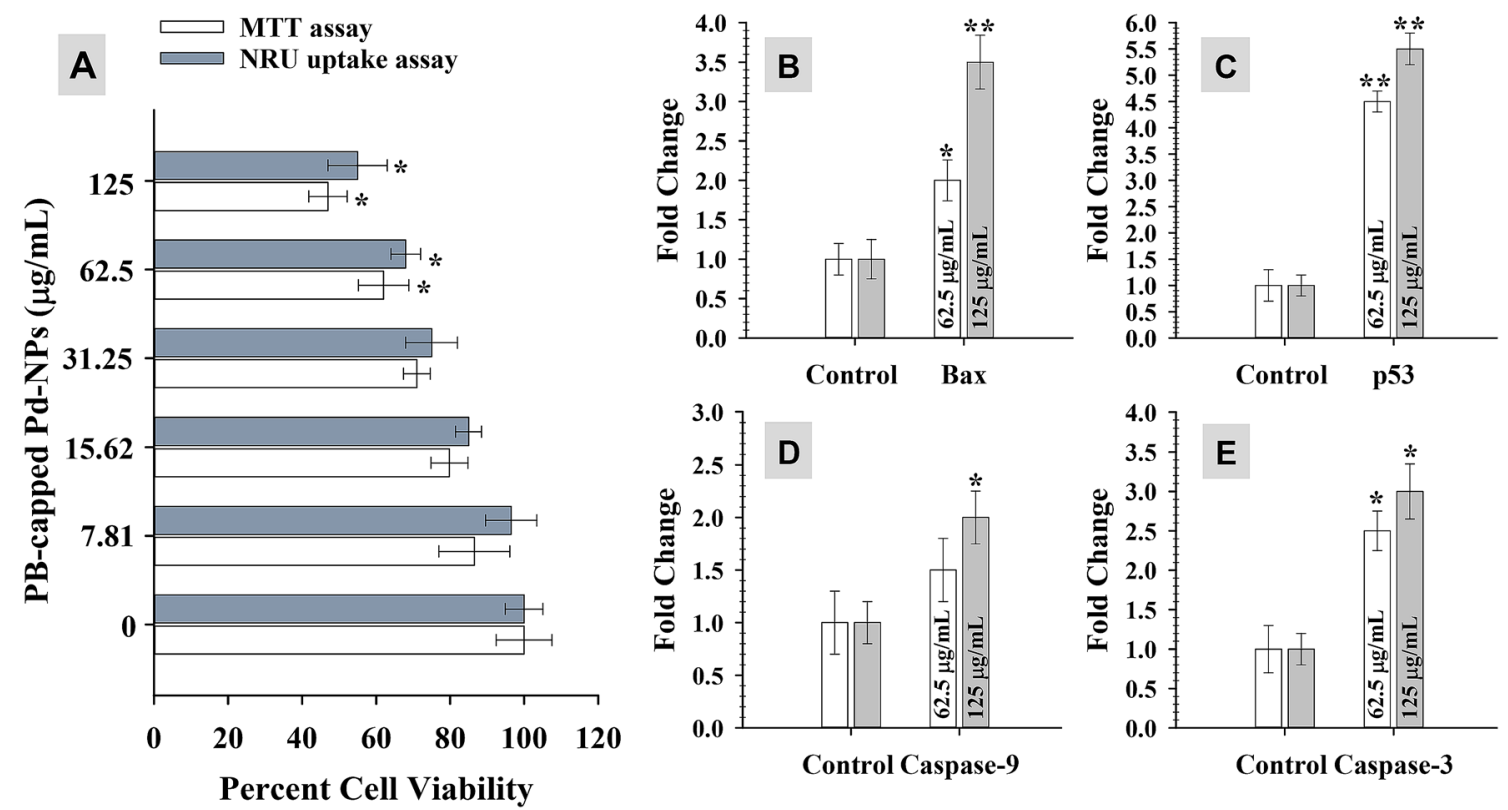

Figure 10. Anti-cancer activity of PB extract-capped Pd-NPs in a concentration $(7.81-250 \mu \mathrm{g} / \mathrm{mL})$ dependent manner as measured by MTT and NRU assays (panel A). Panels B-E shows fold changes in gene expression of four apoptotic genes (bax, $p 53$, caspase-9, and caspase-3). Data represents mean values of three independent replicates and error bars represent standard deviation (S.D.). ${ }^{\star} P \leq 0.05$ and ${ }^{\star *} P \leq 0.01$ as calculated by student's t-test. 


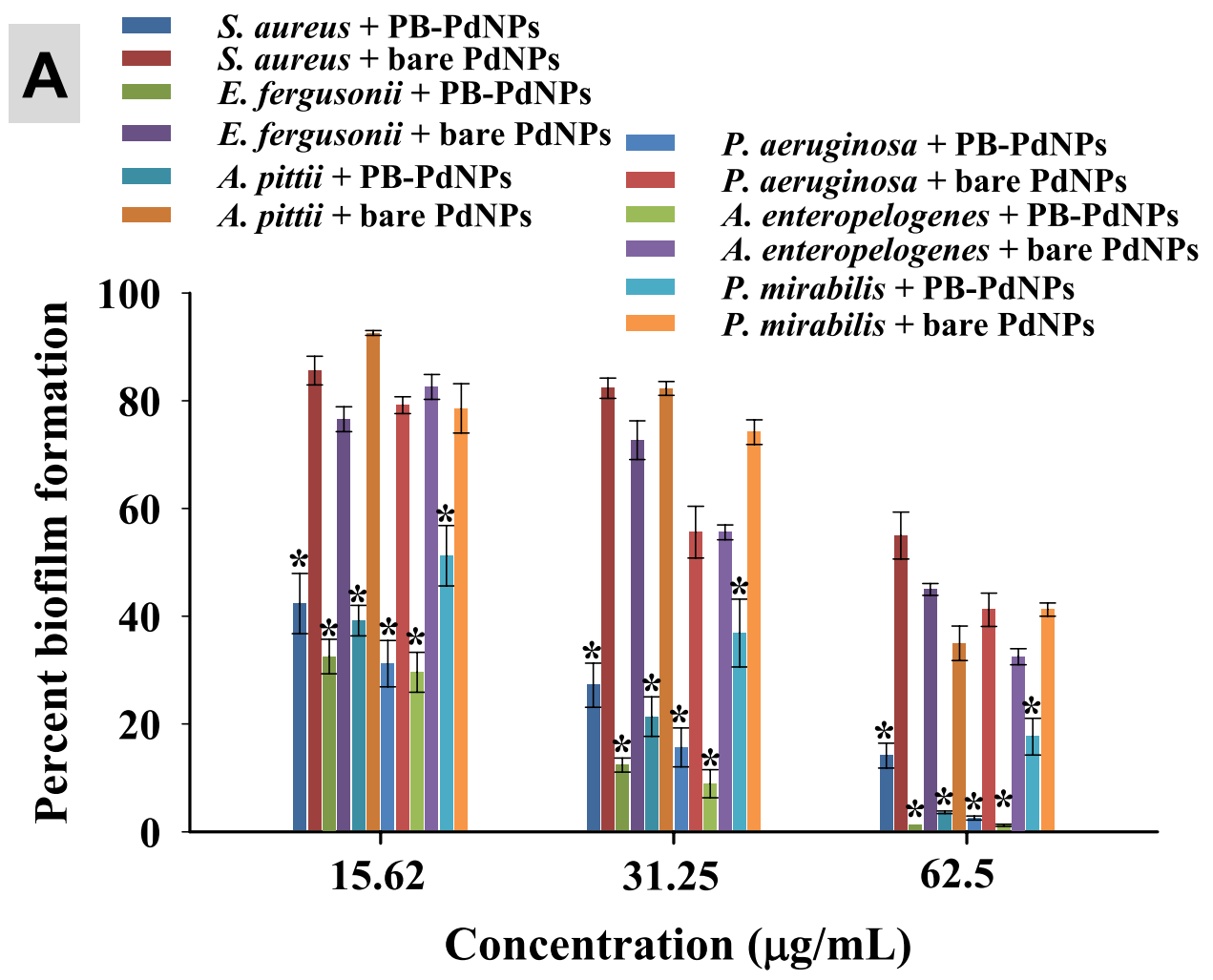

B

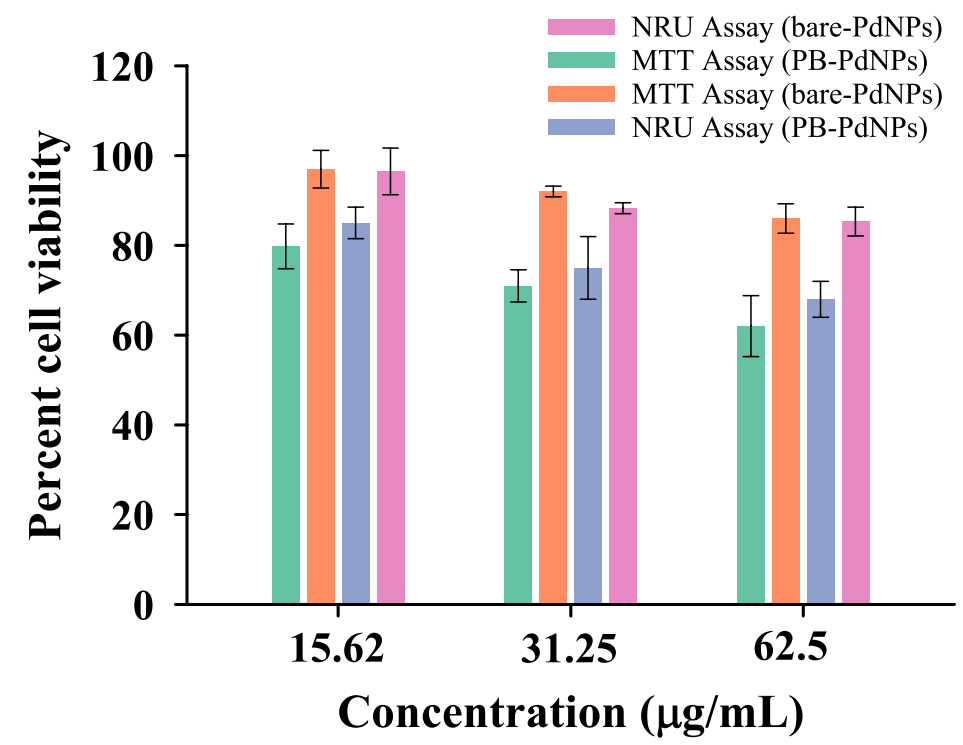

Figure 11. Comparison between the inhibiting potential of $\mathrm{PB}$ extract capped-PdNPs and bare surface Pd-NPs: Antibiofilm activity against six pathogenic strains (panel A) and viability of MCF-7 cells (panel B). Data represents mean values of three independent replicates and error bars represent standard deviation (S.D.). ${ }^{\star} P \leq 0.05$ as calculated by student's t-test.

Received: 21 October 2020; Accepted: 9 February 2021

Published online: 08 March 2021

\section{References}

1. Nikalje, A. P. Nanotechnology and its applications in medicine. Med. Chem. https://doi.org/10.4172/2161-0444.1000247 (2015).

2. Ameen, F. et al. Fabrication of silver nanoparticles employing the cyanobacterium Spirulina platensis and its bactericidal effect against opportunistic nosocomial pathogens of the respiratory tract. J. Mol. Struct. 3, 128392 (2020).

3. Khan, I., Saeed, K. \& Khan, I. Nanoparticles: properties, applications and toxicities. Arab. J. Chem. 12, 908-931 (2019).

4. Ahmed, S., Ahmad, M., Swami, B. L. \& Ikram, S. A review on plants extract mediated synthesis of silver nanoparticles for antimicrobial applications: a green expertise. J. Adv. Res. https://doi.org/10.1016/j.jare.2015.02.007 (2016). 
5. Dahoumane, S. A. et al. Algae-mediated biosynthesis of inorganic nanomaterials as a promising route in nanobiotechnology-a review. Green Chem. https://doi.org/10.1039/c6gc02346k (2017).

6. Saeed, S., Iqbal, A. \& Ashraf, M. A. Bacterial-mediated synthesis of silver nanoparticles and their significant effect against pathogens. Environ. Sci. Pollut. Res. https://doi.org/10.1007/s11356-020-07610-0 (2020).

7. Guilger-Casagrande, M. \& de Lima, R. Synthesis of silver nanoparticles mediated by fungi: a review. Front. Bioeng. Biotechnol. https://doi.org/10.3389/fbioe.2019.00287 (2019).

8. Nuzzo, A., Hosseinkhani, B., Boon, N., Zanaroli, G. \& Fava, F. Impact of bio-palladium nanoparticles (bio-Pd NPs) on the activity and structure of a marine microbial community. Environ. Pollut. https://doi.org/10.1016/j.envpol.2016.11.036 (2017).

9. Al-Saif, S. S. A., Abdel-Raouf, N., El-Wazanani, H. A. \& Aref, I. A. Antibacterial substances from marine algae isolated from Jeddah coast of Red sea, Saudi Arabia. Saudi J. Biol. Sci. https://doi.org/10.1016/j.sjbs.2013.06.001 (2014).

10. Ibraheem, I. B. M., Alharbi, R. M., Abdel-Raouf, N. \& Al-Enazi, N. M. Contributions to the study of the marine algae inhabiting Umluj Seashore, Red Sea. Beni-Suef Univ. J. Basic Appl. Sci. https://doi.org/10.1016/j.bjbas.2014.11.001 (2014).

11. Arya, A., Mishra, V. \& Chundawat, T. S. Green synthesis of silver nanoparticles from green algae (Botryococcus braunii) and its catalytic behavior for the synthesis of benzimidazoles. Chem. Data Collect. https://doi.org/10.1016/j.cdc.2019.100190 (2019).

12. Colin, J. A. et al. Gold nanoparticles synthesis assisted by marine algae extract: Biomolecules shells from a green chemistry approach. Chem. Phys. Lett. https://doi.org/10.1016/j.cplett.2018.08.022 (2018).

13. Abboud, Y. et al. Biosynthesis, characterization and antimicrobial activity of copper oxide nanoparticles (CONPs) produced using brown alga extract (Bifurcaria bifurcata). Appl. Nanosci. https://doi.org/10.1007/s13204-013-0233-x (2014).

14. El-Kassas, H. Y., Aly-Eldeen, M. A. \& Gharib, S. M. Green synthesis of iron oxide $\left(\mathrm{Fe}_{3} \mathrm{O}_{4}\right)$ nanoparticles using two selected brown seaweeds: Characterization and application for lead bioremediation. Acta Oceanol. Sin. https://doi.org/10.1007/s13131-016-0880-3 (2016).

15. Ramkumar, V. S. et al. Synthesis of platinum nanoparticles using seaweed Padina gymnospora and their catalytic activity as PVP/ PtNPs nanocomposite towards biological applications. Biomed. Pharmacother. https://doi.org/10.1016/j.biopha.2017.05.076 (2017).

16. Sayadi, M. H., Salmani, N., Heidari, A. \& Rezaei, M. R. Bio-synthesis of palladium nanoparticle using Spirulina platensis alga extract and its application as adsorbent. Surfaces Interfaces https://doi.org/10.1016/j.surfin.2018.01.002 (2018).

17. Klemm, E. J., Wong, V. K. \& Dougan, G. Emergence of dominant multidrug-resistant bacterial clades: lessons from history and whole-genome sequencing. Proc. Natl. Acad. Sci. U.S.A. https://doi.org/10.1073/pnas.1717162115 (2018).

18. Nikolaou, M., Pavlopoulou, A., Georgakilas, A. G. \& Kyrodimos, E. The challenge of drug resistance in cancer treatment: a current overview. Clin. Exp. Metas. https://doi.org/10.1007/s10585-018-9903-0 (2018).

19. Bao, L. et al. Analysis of some common pathogens and their drug resistance to antibiotics. Pakistan J. Med. Sci. https://doi. org/10.12669/pims.291.2744 (2012).

20. American Cancer Society. Breast Cancer Facts \& Figures 2019-2020. American Cancer Society (2019).

21. Hildebrand, H., Mackenzie, K. \& Kopinke, F. D. Highly active Pd-on-magnetite nanocatalysts for aqueous phase hydrodechlorination reactions. Environ. Sci. Technol. https://doi.org/10.1021/es802726v (2009).

22. Xiong, Y., Huang, L., Mahmud, S., Yang, F. \& Liu, H. Bio-synthesized palladium nanoparticles using alginate for catalytic degradation of azo-dyes. Chin. J. Chem. Eng. https://doi.org/10.1016/j.cjche.2020.02.014 (2020).

23. Phan, T. T. V., Huynh, T. C., Manivasagan, P., Mondal, S. \& Oh, J. An up-to-date review on biomedical applications of palladium nanoparticles. Nanomaterials https://doi.org/10.3390/nano10010066 (2020).

24. Saldan, I., Semenyuk, Y., Marchuk, I. \& Reshetnyak, O. Chemical synthesis and application of palladium nanoparticles. J. Mater. Sci. https://doi.org/10.1007/s10853-014-8802-2 (2015).

25. Moreno-Mañas, M. \& Pleixats, R. Formation of carbon-carbon bonds under catalysis by transition-metal nanoparticles. Acc. Chem. Res. https://doi.org/10.1021/ar020267y (2003).

26. Mpungose, P. P., Vundla, Z. P., Maguire, G. E. M. \& Friedrich, H. B. The current status of heterogeneous palladium catalysed Heck and Suzuki cross-coupling reactions. Molecules https://doi.org/10.3390/molecules23071676 (2018).

27. Sugawa, K. et al. Refractive index susceptibility of the plasmonic palladium nanoparticle: Potential as the third plasmonic sensing material. ACS Nano https://doi.org/10.1021/nn506800a (2015).

28. Khalid, S., Abbas, M., Saeed, F., Bader-Ul-Ain, H. \& Ansar, R. S. H. Therapeutic potential of Seaweed bioactive compounds. Seaweed Biomater. https://doi.org/10.5772/intechopen.74060 (2018).

29. Sameeh, M. Y., Mohamed, A. A. \& Elazzazy, A. M. Polyphenolic contents and antimicrobial activity of different extracts of Padina boryana Thivy and Enteromorpha sp. marine algae. J. Appl. Pharm. Sci. https://doi.org/10.7324/JAPS.2016.60913 (2016).

30. Sangeetha, A. \& Poonguzhali, T. V. Studies on the phytochemical analysis and antioxidant activity of Padina boryana Thivy. Indian J. Res. 9, 15 (2020).

31. Jayawardena, T. U. et al. Padina boryana, a brown alga from the Maldives: Inhibition of a-MSH-stimulated melanogenesis via the activation of ERK in B16F10 cells. Fisheries Aquatic Sci. https://doi.org/10.1186/s41240-020-00154-x (2020).

32. Alsamhary, K., Al-Enazi, N., Alshehri, W. A. \& Ameen, F. Gold nanoparticles synthesised by flavonoid tricetin as a potential antibacterial nanomedicine to treat respiratory infections causing opportunistic bacterial pathogens. Microb. Pathog. 139, 103928 (2020).

33. CLSI. Performance Standards for Antimicrobial Susceptibility Testing CLSI supplement M100S. Clinical and Laboratory Standards Institute, Wayne, PA. (2016).

34. Munita, J. M., Arias, C. A., Unit, A. R. \& Santiago, A. HHS public access mechanisms of antibiotic resistance. HHS Public Access 4, 1-37 (2016).

35. Devi, K. R., Srinivasan, S. \& Ravi, A. V. Inhibition of quorum sensing-mediated virulence in Serratia marcescens by Bacillus subtilis R-18. Microb. Pathog. https://doi.org/10.1016/j.micpath.2018.04.023 (2018).

36. Housman, G. et al. Drug resistance in cancer: an overview. Cancers https://doi.org/10.3390/cancers6031769 (2014).

37. Kanchana, A., Devarajan, S. \& Ayyappan, S. R. Green synthesis and characterization of palladium nanoparticles and its conjugates from solanum trilobatum leaf extract. Nano-Micro Lett. https://doi.org/10.5101/nml.v2i3.p169-176 (2010).

38. Dauthal, P. \& Mukhopadhyay, M. Biosynthesis of palladium nanoparticles using delonix regia leaf extract and its catalytic activity for nitro-aromatics hydrogenation. Ind. Eng. Chem. Res. https://doi.org/10.1021/ie403410z (2013).

39. Behzadi, S. et al. Determination of nanoparticles using UV-Vis spectra. Nanoscale https://doi.org/10.1039/c4nr00580e (2015).

40. Yang, X. et al. Green synthesis of palladium nanoparticles using broth of Cinnamomum camphora leaf. J. Nanopart. Res. https:// doi.org/10.1007/s11051-009-9675-1 (2010).

41. Bankar, A., Joshi, B., Kumar, A. R. \& Zinjarde, S. Banana peel extract mediated novel route for the synthesis of palladium nanoparticles. Mater. Lett. https://doi.org/10.1016/j.matlet.2010.06.021 (2010).

42. Li, J. et al. Aqueous controllable synthesis of spindle-like palladium nanoparticles and their application for catalytic reduction of 4-nitrophenol. Progress Nat. Sci. Mater. Int. https://doi.org/10.1016/j.pnsc.2016.05.013 (2016).

43. Sharmila, G. et al. Green synthesis, characterization and antibacterial efficacy of palladium nanoparticles synthesized using Filicium decipiens leaf extract. J. Mol. Struct. https://doi.org/10.1016/j.molstruc.2017.02.097 (2017).

44. Bhattacharjee, S. DLS and zeta potential-What they are and what they are not?. J. Control. Release 235, 337-351 (2016).

45. Edison, T. J. I. \& Sethuraman, M. G. Instant green synthesis of silver nanoparticles using Terminalia chebula fruit extract and evaluation of their catalytic activity on reduction of methylene blue. Process Biochem. https://doi.org/10.1016/j.procbio.2012.04.025 (2012). 
46. Santoshi, K. A., Venkatesham, M., Ayodhya, D. \& Veerabhadram, G. Green synthesis, characterization and catalytic activity of palladium nanoparticles by xanthan gum. Appl. Nanosci. https://doi.org/10.1007/s13204-014-0320-7 (2015).

47. Guidelli, E. J., Ramos, A. P., Zaniquelli, M. E. D. \& Baffa, O. Green synthesis of colloidal silver nanoparticles using natural rubber latex extracted from Hevea brasiliensis. Spectrochimica Acta Part A Mol. Biomol. Spectr. https://doi.org/10.1016/j.saa.2011.07.024 (2011).

48. Ali, K. et al. Microwave accelerated green synthesis of stable silver nanoparticles with Eucalyptus globulus leaf extract and their antibacterial and antibiofilm activity on clinical isolates. PLOS ONE 10, 15 (2015).

49. Wang, T., Jin, X., Chen, Z., Megharaj, M. \& Naidu, R. Green synthesis of Fe nanoparticles using eucalyptus leaf extracts for treatment of eutrophic wastewater. Sci. Total Environ. 466-467, 210-213 (2014).

50. Leenheer, J. A., Nanny, M. A. \& McIntyre, C. Terpenoids as major precursors of dissolved organic matter in landfill leachates, surface water, and groundwater. Environ. Sci. Technol. https://doi.org/10.1021/es0264089 (2003).

51. Hamberger, B. \& Bak, S. Plant P450s as versatile drivers for evolution of species-specific chemical diversity. Philos. Trans. R. Soc. B Biol. Sci. https://doi.org/10.1098/rstb.2012.0426 (2013).

52. Kajiwara, T. et al. Distribution of an enzyme system producing seaweed flavor: conversion of fatty acids to long-chain aldehydes in seaweeds. J. Appl. Phycol. https://doi.org/10.1007/BF00004022 (1993).

53. Horincar, V. B. et al. Extraction and characterization of volatile compounds and fatty acids from red and green macroalgae from the Romanian Black Sea in order to obtain valuable bioadditives and biopreservatives. J. Appl. Phycol. https://doi.org/10.1007/ s10811-013-0053-0 (2014).

54. Johns, R. B., Nichols, P. D. \& Perry, G. J. Fatty acid composition of ten marine algae from australian waters. Phytochemistry https ://doi.org/10.1016/0031-9422(79)80018-7 (1979).

55. Lavergne, F. D. et al. GC-MS metabolomics to evaluate the composition of plant cuticular waxes for four Triticum aestivum cultivars. Int. J. Mol. Sci. https://doi.org/10.3390/ijms19020249 (2018).

56. Syeda, A. M. \& Riazunnisa, K. Data on GC-MS analysis, in vitro anti-oxidant and anti-microbial activity of the Catharanthus roseus and Moringa oleifera leaf extracts. Data Brief https://doi.org/10.1016/j.dib.2020.105258 (2020).

57. Saleem, S., Ahmed, B., Khan, M. S., Al-Shaeri, M. \& Musarrat, J. Inhibition of growth and biofilm formation of clinical bacterial isolates by $\mathrm{NiO}$ nanoparticles synthesized from Eucalyptus globulus plants. Microb. Pathog. 111, 375-387 (2017).

58. Cho, G. S. et al. Diversity and antibiotic susceptibility of Acinetobacter strains from milk powder produced in Germany. Front. Microbiol. https://doi.org/10.3389/fmicb.2018.00536 (2018).

59. Wimalasena, S. H. M. P., Shin, G. W., Hossain, S. \& Heo, G. J. Potential enterotoxicity and antimicrobial resistance pattern of Aeromonas species isolated from pet turtles and their environment. J. Vet. Med. Sci. https://doi.org/10.1292/jvms.16-0493 (2017).

60. Mirzaei, A., Habibi, M., Bouzari, S. \& Karam, M. R. A. Characterization of antibiotic-susceptibility patterns, virulence factor profiles and clonal relatedness in proteus mirabilis isolates from patients with urinary tract infection in Iran. Infection Drug Resistance https ://doi.org/10.2147/IDR.S230303 (2019).

61. Glover, B., Wentzel, J., Jenkins, A. \& Van Vuuren, M. The first report of Escherichia fergusonii isolated from non-human primates Africa. One Health 3, 70-75 (2017).

62. Rabiee, N., Bagherzadeh, M., Kiani, M. \& Ghadiri, A. M. Rosmarinus officinalis directed palladium nanoparticle synthesis: Investigation of potential anti-bacterial, anti-fungal and Mizoroki-Heck catalytic activities. Adv. Powder Technol. https://doi.org/10.1016/j. apt.2020.01.024 (2020).

63. Tahir, K. et al. Sapium sebiferum leaf extract mediated synthesis of palladium nanoparticles and in vitro investigation of their bacterial and photocatalytic activities. J. Photochem. Photobiol. B https://doi.org/10.1016/j.jphotobiol.2016.09.030 (2016).

64. Saeki, E. K., Kobayashi, R. K. T. \& Nakazato, G. Quorum sensing system: target to control the spread of bacterial infections. Microb. Pathog. 142, 104068 (2020).

65. Murugesan, B. et al. Fabrication of palladium nanoparticles anchored polypyrrole functionalized reduced graphene oxide nanocomposite for antibiofilm associated orthopedic tissue engineering. Appl. Surf. Sci. https://doi.org/10.1016/j.apsusc.2020.145403 (2020).

66. Azizi, S. et al. Green synthesis palladium nanoparticles mediated by white tea (Camellia sinensis) extract with antioxidant, antibacterial, and antiproliferative activities toward the human leukemia (MOLT-4) cell line. Int. J. Nanomed. https://doi.org/10.2147/ IJN.S149371 (2017).

67. Saha, K., Agasti, S. S., Kim, C., Li, X. \& Rotello, V. M. Gold nanoparticles in chemical and biological sensing. Chem. Rev. https:// doi.org/10.1021/cr2001178 (2012).

68. Ali, K., Ahmed, B., Khan, M. S. \& Musarrat, J. Differential surface contact killing of pristine and low EPS Pseudomonas aeruginosa with Aloe vera capped hematite $\left(\alpha-\mathrm{Fe}_{2} \mathrm{O}_{3}\right)$ nanoparticles. J. Photochem. Photobiol. B 188, 146-158 (2018).

69. Ali, K. et al. Comparative in situ ROS mediated killing of bacteria with bulk analogue, Eucalyptus leaf extract (ELE)-capped and bare surface copper oxide nanoparticles. Mater. Sci. Eng., C 100, 13895 (2019).

\section{Acknowledgements}

The authors extend their appreciation to the researcher Sohailah Alotaibi for her support during practical work.

\section{Author contributions}

All authors contributed to data analysis, drafting, or revising the manuscript. All authors approved the final manuscript and are accountable for all aspects of the work.

\section{Funding}

This research was funded by the Deanship of Scientific Research at Princess Nourah bint Abdulrahman University, through the Research Funding Program (Grant No FRP-1441- 11).

\section{Competing interests}

The authors declare no competing interests.

\section{Additional information}

Supplementary Information The online version contains supplementary material available at https://doi. org/10.1038/s41598-021-84794-6.

Correspondence and requests for materials should be addressed to F.A.

Reprints and permissions information is available at www.nature.com/reprints. 
Publisher's note Springer Nature remains neutral with regard to jurisdictional claims in published maps and institutional affiliations.

(c) (i) Open Access This article is licensed under a Creative Commons Attribution 4.0 International License, which permits use, sharing, adaptation, distribution and reproduction in any medium or format, as long as you give appropriate credit to the original author(s) and the source, provide a link to the Creative Commons licence, and indicate if changes were made. The images or other third party material in this article are included in the article's Creative Commons licence, unless indicated otherwise in a credit line to the material. If material is not included in the article's Creative Commons licence and your intended use is not permitted by statutory regulation or exceeds the permitted use, you will need to obtain permission directly from the copyright holder. To view a copy of this licence, visit http://creativecommons.org/licenses/by/4.0/.

(C) The Author(s) 2021 